\title{
Seasonal characterization of submicron aerosol chemical composition and organic aerosol sources in the southeastern United States: Atlanta, Georgia, and Look Rock, Tennessee
}

\author{
Sri Hapsari Budisulistiorini ${ }^{1}$, Karsten Baumann ${ }^{2}$, Eric S. Edgerton ${ }^{2}$, Solomon T. Bairai ${ }^{3}$, Stephen Mueller $^{4}$, \\ Stephanie L. Shaw ${ }^{5}$, Eladio M. Knipping ${ }^{6}$, Avram Gold ${ }^{1}$, and Jason D. Surratt ${ }^{1}$ \\ ${ }^{1}$ Department of Environmental Sciences and Engineering, Gillings School of Global Public Health, \\ The University of North Carolina at Chapel Hill, Chapel Hill, NC, USA \\ ${ }^{2}$ Atmospheric Research \& Analysis, Inc., Cary, NC, USA \\ ${ }^{3}$ Battelle, Pueblo, CO, USA \\ ${ }^{4}$ Ensafe, Nashville, TN, USA \\ ${ }^{5}$ Electric Power Research Institute, Palo Alto, CA, USA \\ ${ }^{6}$ Electric Power Research Institute, Washington, DC, USA
}

Correspondence to: J. D. Surratt (surratt@unc.edu)

Received: 29 July 2015 - Published in Atmos. Chem. Phys. Discuss.: 20 August 2015

Revised: 13 April 2016 - Accepted: 17 April 2016 - Published: 26 April 2016

\begin{abstract}
A year-long near-real-time characterization of non-refractory submicron aerosol $\left(\mathrm{NR}-\mathrm{PM}_{1}\right)$ was conducted at an urban (Atlanta, Georgia, in 2012) and rural (Look Rock, Tennessee, in 2013) site in the southeastern US using the Aerodyne Aerosol Chemical Speciation Monitor (ACSM) collocated with established air-monitoring network measurements. Seasonal variations in organic aerosol (OA) and inorganic aerosol species are attributed to meteorological conditions as well as anthropogenic and biogenic emissions in this region. The highest concentrations of NR-PM 1 were observed during winter and fall seasons at the urban site and during spring and summer at the rural site. Across all seasons and at both sites, NR-PM 1 was composed largely of OA (up to $76 \%$ ) and sulfate (up to $31 \%$ ). Six distinct OA sources were resolved by positive matrix factorization applied to the ACSM organic mass spectral data collected from the two sites over the 1 year of near-continuous measurements at each site: hydrocarbon-like OA (HOA), biomass burning OA (BBOA), semi-volatile oxygenated OA (SV-OOA), low-volatility oxygenated OA (LV-OOA), isoprene-derived epoxydiols (IEPOX) OA (IEPOX-OA) and 91Fac (a factor dominated by a distinct ion at $m / z 91$ fragment ion previously observed in biogenic influenced areas). LV-OOA was
\end{abstract}

observed throughout the year at both sites and contributed up to $66 \%$ of total OA mass. HOA was observed during the entire year only at the urban site (on average $21 \%$ of OA mass). BBOA (15-33\% of OA mass) was observed during winter and fall, likely dominated by local residential wood burning emission. Although SV-OOA contributes quite significantly ( $\sim 27 \%$ ), it was observed only at the urban site during colder seasons. IEPOX-OA was a major component (27-41\%) of $\mathrm{OA}$ at both sites, particularly in spring and summer. An ion fragment at $m / z 75$ is well correlated with the $m / z 82$ ion associated with the aerosol mass spectrum of IEPOX-derived secondary organic aerosol (SOA). The contribution of $91 \mathrm{Fac}$ to the total OA mass was significant (on average $22 \%$ of OA mass) at the rural site only during warmer months. Comparison of 91Fac OA time series with SOA tracers measured from filter samples collected at Look Rock suggests that isoprene oxidation through a pathway other than IEPOX SOA chemistry may contribute to its formation. Other biogenic sources could also contribute to $91 \mathrm{Fac}$, but there remains a need to resolve the exact source of this factor based on its significant contribution to rural OA mass. 


\section{Introduction}

Characterization of the chemical composition of atmospheric fine aerosol is important, because of its adverse human health effects (Pope III and Dockery, 2006) and possible impacts on the Earth's climate system (Forster et al., 2007). Aerosol with aerodynamic diameters $\leq 1 \mu \mathrm{m}\left(\mathrm{PM}_{1}\right)$ plays a significant role in scattering and/or absorbing solar radiation as well as cloud formation (IPCC, 2013). Long-term regional characterizations of ambient $\mathrm{PM}_{1}$ are required to understand its sources, formation and aging mechanisms, as well as atmospheric lifetime. This information will lead to more accurately constrained air quality models for making regulatory decisions to mitigate the potential adverse impacts of $\mathrm{PM}_{1}$.

Over the past decade, online aerosol mass spectrometry (AMS) has been used to extensively characterize ambient non-refractory (NR)-PM $\mathrm{PM}_{1}$ (Zhang et al., 2007; Jimenez et al., 2009; Ng et al., 2010; Crippa et al., 2014); however, prior studies were limited by short measurement periods (weeks to a several months) because the need for intensive instrument maintenance required the continuous on-site presence of skilled personnel in order to generate high-quality data. The Aerodyne Aerosol Chemical Speciation Monitor (ACSM) based on the AMS technology has been modified to allow for long-term operation with less maintenance $(\mathrm{Ng}$ et al., 2011b). The ACSM has been recently used for longterm NR-PM 1 measurements (Petit et al., 2015; Ripoll et al., 2015; Parworth et al., 201; Zhang et al., 2015) and shown to be durable and data are comparable to data collected from existing fine aerosol monitoring networks (Budisulistiorini et al., 2014).

Worldwide studies have shown that tropospheric $\mathrm{PM}_{1}$ mass is dominated by organic aerosol (OA; Zhang et al., 2007; Jimenez et al., 2009). OA consists of aerosol directly emitted into the atmosphere, primary organic aerosol (POA) and aerosol formed from atmospheric oxidation of volatile organic compounds (VOCs), secondary organic aerosol (SOA). POA sources include fossil fuel combustion from vehicles, power generation, and residential burning (cooking and heating) as well as forest fires (Kanakidou et al., 2005). Contribution of hydrocarbon-like OA (HOA) associated with POA to urban OA mass may be significant during morning traffic, while oxygenated OA (OOA) associated with SOA exceeds POA at midday or in the afternoon (Zhang et al., 2005). SOA has been observed to contribute upwards of $90 \%$ to the total OA mass (Docherty et al., 2008), indicating the critical role of photochemical processes in SOA formation.

Studies in Atlanta, Georgia, have characterized the chemical components of ambient aerosol collected during different seasons (Lee et al., 2002; Kim et al., 2003; Butler et al., 2003); however, they were limited by low time or mass resolution. A recent study reported characterization of ambient NR-PM 1 by high-resolution time-of-flight AMS (HRToF-AMS) from multiple sites in Georgia, including Atlanta,
Table 1. Seasonal classification of measurements at JST and LRK is based on direction of angle of the Earth to the sun and the angle of the sunlight as it hits the Earth.

\begin{tabular}{lcc}
\hline & JST & LRK \\
\hline Winter & $22 / 12 / 2011-19 / 03 / 2012$ & $18 / 01 / 2013-19 / 03 / 2013$ \\
Spring & $20 / 03 / 2012-19 / 06 / 2012$ & $20 / 03 / 2013-31 / 05 / 2013$ \\
Summer & $20 / 06 / 2012-21 / 09 / 2012$ & $01 / 06 / 2013-21 / 09 / 2013^{*}$ \\
Fall & $22 / 09 / 2012-20 / 12 / 2012$ & $22 / 09 / 2013-20 / 12 / 2013$ \\
\hline
\end{tabular}

${ }^{*}$ Measurements in summer at the LRK site included in the 2013 SOAS campaign from 1 June to 17 July 2013.

but was limited by 1-month measurement periods at each site (Xu et al., 2015a). Non-fossil carbon derived from modern sources (e.g., biogenic) is reported to account for $50 \%$ of carbon at two urban sites and $70-100 \%$ of carbon at 10 near-urban or remote sites in the US (Schichtel et al., 2008). Additionally, isoprene-derived SOA was recently observed to contribute substantially to SOA in downtown Atlanta during summer (Budisulistiorini et al., 2013; Xu et al., 2015a, b). The isoprene-derived SOA was attributed to the heterogeneous chemistry of isomeric isoprene epoxydiols (IEPOX), known oxidation products of isoprene under both low- (Paulot et al., 2009) and high-NO (Jacobs et al., 2014) conditions, in the presence of acidic sulfate aerosol (Budisulistiorini et al., 2013).

Biogenic hydrocarbons and their oxidation products are major contributors to ambient fine aerosol in rural areas where anthropogenic sources are low (Budisulistiorini et al., 2015). In summer 2001, the fraction of non-fossil carbon was reported to vary from 66 to $80 \%$ of total carbon at Look Rock (LRK), Great Smoky Mountains National Park (GSMNP), Tennessee (TN), indicating the likely importance of photochemical oxidation of biogenic VOCs (BVOCs; Tanner et al., 2004a). Sulfate did not show significant diurnal variability at LRK, TN, suggesting that local meteorological conditions are less influential in determining concentrations of long-lived species (Tanner et al., 2005). SOA is a predominant component of $\mathrm{PM}_{2.5}$ mass during summer and early fall but POA is more dominant in the late fall (Ke et al., 2007), suggesting that the LRK site is influenced by biogenic and anthropogenic emissions.

We present a 2-year study comparing near-real-time chemical characterizations of NR-PM 1 collected for 1-year at the urban Jefferson Street (JST) site in downtown Atlanta, Georgia (GA), and a subsequent year at the rural LRK site located in the GSMNP, TN. NR-PM 1 was sampled, chemically characterized and quantified over a 2-year period, spanning 2012-2013 using the ACSM. OA sources were seasonally analyzed by positive matrix factorization (PMF). OA factors resolved by PMF were compared with collocated data collected from both air-monitoring sites in order to associate them with specific types of OA sources. 


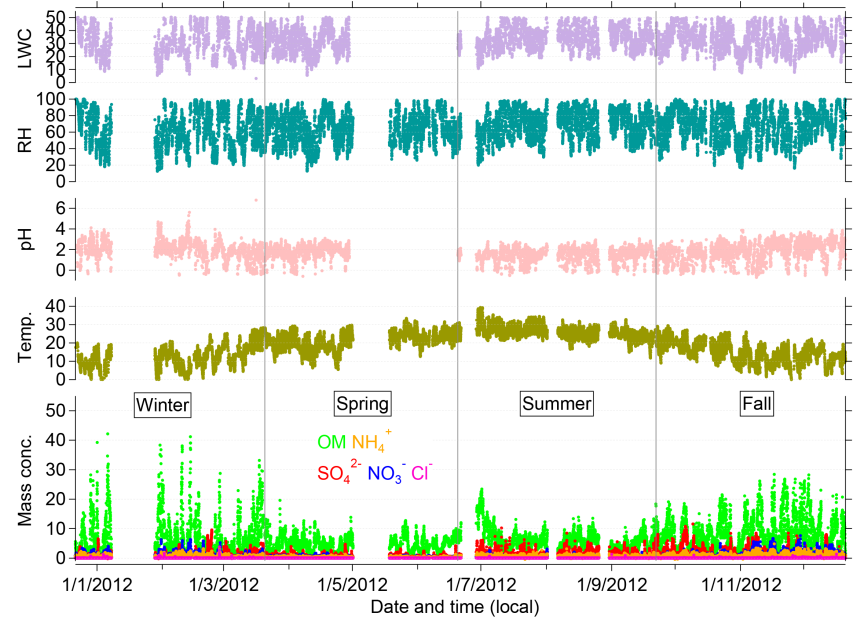

Figure 1. Annual temporal variations of $\mathrm{OA}$ and inorganic species $\left(\mu \mathrm{g} \mathrm{m}^{-3}\right)$ measured at the Jefferson Street (JST) site, Atlanta, Georgia, in 2012. Included in the plots are ambient temperature $\left({ }^{\circ} \mathrm{C}\right)$ and relative humidity (RH, in \%) measured by SEARCH network, as well as $\mathrm{pH}$ and liquid water content $\left(\mathrm{LWC}\right.$, in $\left.\mathrm{mol} \mathrm{L}^{-1}\right)$ estimated by ISORROPIA-II.

\section{Methods}

\subsection{Fine aerosol sampling and data analysis}

Real-time continuous chemical measurements were conducted during 2012 at a downtown urban site (JST) in Atlanta, GA, and during 2013 at a rural/forested site (LRK) in GSMNP, TN, respectively. Analysis of data obtained from measurements at JST and LRK was classified by season (Table 1), which was able to capture changes in meteorology, in particular ambient temperature, at JST in 2012 and LRK in 2013 as illustrated in Figs. 1 and 2. The period with the coldest temperatures is classified as the winter season, and when the temperature rises, the period is classified as the spring season. Summer season is signified by constant high temperature at the JST and LRK sites. When temperature decreases after summer, this period is categorized as the fall season.

Organic and inorganic species characterizations during the 2013 Southern Oxidant Aerosol Study (SOAS; Budisulistiorini et al., 2015) were included in analysis of the summer season at the LRK site in this study. Detailed descriptions of both sites have been published (Budisulistiorini et al., 2013, 2015). Briefly, the JST site is one of several research sites of the Southeastern Aerosol Research and Characterization (SEARCH) network. The JST site is located in a mixed industrial-residential area about $4.2 \mathrm{~km}$ northwest of downtown Atlanta and within approximately $200 \mathrm{~m}$ of a bus maintenance yard and several warehouse facilities to the south and southwest (Hansen et al., 2003; Solomon et al., 2003), and within $53 \mathrm{~km}$ of a coal-fired power plant (Plant Bowen; Edgerton et al., 2006). The LRK site is located on a ridge top on the northwestern edge of the GSMNP down-

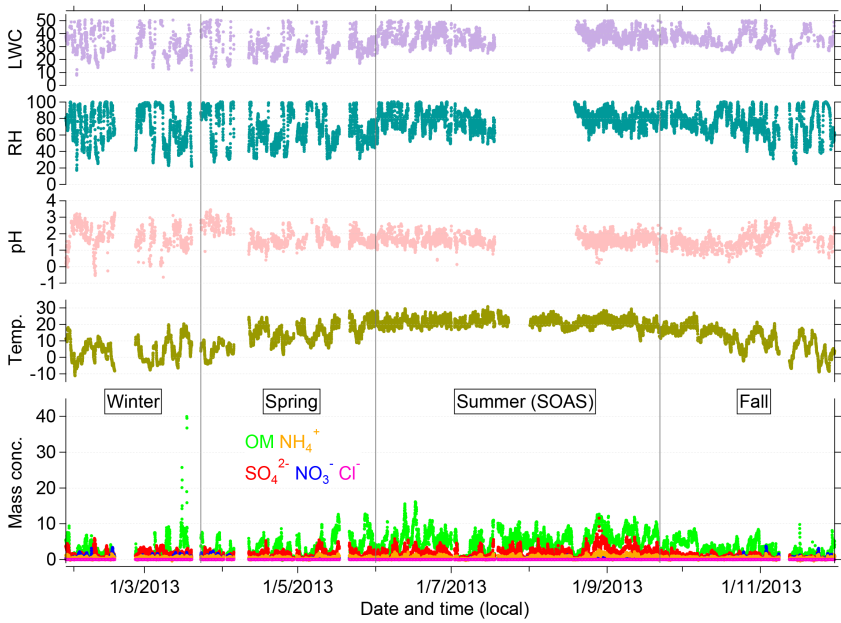

Figure 2. Annual temporal variations of OA and inorganic species $\left(\mu \mathrm{g} \mathrm{m}^{-3}\right)$ measured at the Look Rock (LRK) site, Great Smoky Mountains, Tennessee, in 2013. Included in the plots are ambient temperature and $\mathrm{RH}(\%)$ measured by Tennessee Valley Authority (TVA), as well as $\mathrm{pH}$ and $\mathrm{LWC}\left(\mathrm{mol} \mathrm{L}^{-1}\right)$ estimated by ISORROPIA-II.

wind of urban areas, such as Knoxville and Maryville, TN, and small farms with animal grazing areas. Coal-fired power plants Kingston and Bull Run are located within 50-60 km northwest of LRK site (Tennessee Valley Authority, 2015). In summer, up-slope flow carries pollutants emitted in the valley during early morning to the LRK site by mid-morning, and in the evening down-slope flow accompanies a shift of wind direction to the south and east that could isolate the site from fresh primary emissions from the valley and allows aged secondary species to accumulate (Tanner et al., 2005).

Ambient NR-PM 1 was analyzed using the Aerodyne ACSM in a similar manner at both sites. Details of NR-PM sampling at the JST and LRK sites have been described in Budisulistiorini et al. (2013, 2015). Briefly, the ACSM was operated with a sampling flow rate of $3 \mathrm{~L} \mathrm{~min}^{-1}$, resulting in a residence time of $<2 \mathrm{~s}$ for $\mathrm{PM}_{2.5}$ in the sampling line. The aerodynamic lens mounted on the ACSM inlet continuously samples $\mathrm{PM}_{1}$ from the bypass $\mathrm{PM}_{2.5}$ sampling line ( $\mathrm{Ng}$ et al., 2011b). Particle-laden air was dried using a 50-tube Nafion dryer (Perma Pure PD-50T-24SS) in which a dry-air system delivered $7 \mathrm{~L} \mathrm{~min}^{-1}$ of dry sheath air to keep the sample air relative humidity $(\mathrm{RH})$ well below $10 \%$, preventing condensation within the sampling line that could adversely affect the collection efficiency (CE) of $\mathrm{PM}_{1}$ and clog the ACSM sampling inlet. The ACSM was tuned for ionizer and electronic offset and calibrated for ionization efficiency on-site (five to seven times) throughout each year of sampling at each site. Mass calculation of aerosol constituents is described in detail elsewhere (Ng et al., 2011b). At both sites, a CE value of 0.5 for all species was used based on evaluation of compositiondependent CE as described in Budisulistiorini et al. (2013, 
2015). We estimated dry density of ambient $\mathrm{PM}_{1}$ based on average particle composition for each season, and the assumption of organic, inorganic and elemental carbon (EC) densities are 1.4 (Hallquist et al., 2009), 1.77 (Turpin and Lim, 2001), and $1.77 \mathrm{~g} \mathrm{~cm}^{-3}$ (Park et al., 2004), respectively. The estimated dry aerosol densities at both the JST and LRK sites are $1.55 \mathrm{~g} \mathrm{~cm}^{-3}$ on average (Table $\mathrm{S} 1$ in the Supplement), which is about $13 \%$ less than the density of 1.75 at JST (Budisulistiorini et al., 2014) and similar to the density of $1.52 \mathrm{~g} \mathrm{~cm}^{-3}$ at LRK (Budisulistiorini et al., 2015) during summer. If a CE of 1 was applied to JST and LRK data sets, the estimated aerosol density is $<1 \mathrm{~g} \mathrm{~cm}^{-3}$, which is much lower than the suggested organic of $1.4 \mathrm{~g} \mathrm{~cm}^{-3}$ (Hallquist et al., 2009) and inorganic aerosol density of $1.77 \mathrm{~g} \mathrm{~cm}^{-3}$ (Cross et al., 2007). Therefore, we applied a CE value of 0.5 to all seasonal data sets.

\subsection{Organic aerosol characterization by PMF}

Details of PMF analysis of the organic mass fraction have been described previously (Lanz et al., 2007; Ulbrich et al., 2009; Zhang, 2011). The PMF2 algorithm (Paatero and Tapper, 1994) was used in robust mode via PMF Evaluation Tool panel (PET v2.04) using the methods outlined in Ulbrich et al. (2009) and Zhang et al. (2011). Only the mass range $m / z 12-120$ was utilized for PMF because no organic fragment ions are possible at $m / z<12$ and low transmission efficiency for ions with $\mathrm{m} / z>120$ ( $\mathrm{Ng}$ et al., 2011b), which results in low signal-to-noise ratios as well as possible interference from naphthalene calibrant at $m / z 128$.

PMF analysis of year-long data collected from JST and LRK yielded similar factor solutions as those obtained from seasonal data, but showed additional factor splitting that made solid identification of unique factors difficult. Therefore, we present results from PMF analysis performed separately for winter, spring, summer and fall seasons for the JST and LRK sites. Solutions were chosen based on the quality of PMF fits as well as interpretability when compared to reference mass spectra ( $\mathrm{Ng}$ et al., 2011a; Robinson et al., 2011) and independent gas- and particle-phase measurements (Budisulistiorini et al., 2013, 2015). For each analysis, uncertainty of selected factor solutions was investigated with different seeds (seed parameter varied from 0 to 100 , in steps of 5), FPEAK parameters, and 100 bootstrapping runs. PMF analysis of each season is detailed in Figs. S1S24 in the Supplement and correlations of selected PMF factors with external tracers and reference mass spectra are provided in Tables S2-S3. $Q / Q_{\exp }$ from PMF analysis of JST data for all four seasons is $2.2-2.9$, indicating that the errors are somewhat underestimated (Ulbrich et al., 2009). This could be due to some missing data points and the lack of distinct time series during nighttime due to atmospheric stability and limitation of ACSM measurements (not high-resolution), such as observed by Guha et al. (2015). $Q / Q_{\text {exp }}$ from PMF analysis of LRK data for all four seasons is between 0.15
0.28 , suggesting that the errors are overestimated (Ulbrich et al., 2009). However, the error values are deemed appropriate since $Q / Q_{\exp }$ is consistently less than unity, regardless of the number of factors and the data sets.

\subsection{Estimation of aerosol acidity by ISORROPIA}

The thermodynamic model, ISORROPIA-II, in forward mode (Fountoukis and Nenes, 2007; Nenes et al., 1999), was used to estimate aerosol $\mathrm{pH}$. Inputs for the model include aerosol-phase sulfate, nitrate, and ammonium as $\mu \mathrm{mol} \mathrm{m} \mathrm{m}^{-3}$, measured by the ACSM under ambient conditions. In addition, RH and temperature obtained from the SEARCH network and the National Park Service (NPS) for JST and LRK sites, respectively, were used as inputs. Inputs of gas-phase ammonia for the JST site were obtained from SEARCH and for the LRK site, from the Ammonia Monitoring Network (AMoN, TN01/Great Smoky Mountains National Park - Look Rock). ISORROPIA-II predicted particle hydronium ion concentration per volume of air $\left(\mathrm{H}^{+}, \mu \mathrm{g} \mathrm{m}^{-3}\right)$ and aerosol liquid water content ( $\left.\mathrm{LWC}, \mathrm{mol} \mathrm{L}^{-1}\right)$. Calculation of aerosol $\mathrm{pH}$ follows that of Eq. (1) in Budisulistiorini et al. (2015).

\section{Results}

Seasonally averaged NR-PM 1 was typically higher at JST in $2012\left(6-13 \mu \mathrm{g} \mathrm{m}^{-} 3\right)$ compared to LRK in 2013 (5$8 \mu \mathrm{g} \mathrm{m}^{-3}$ ), especially during colder seasons (fall and winter; Table 2). However, during warmer seasons (spring and summer) the average NR-PM ${ }_{1}$ concentrations were similar at both sites. The highest average seasonal concentration of $\mathrm{NR}-\mathrm{PM}_{1}$ at JST was observed during the fall $\left(12.5 \mu \mathrm{g} \mathrm{m}^{-3}\right)$, whereas the summer season yielded the highest average NR$\mathrm{PM}_{1}$ concentration at the LRK site $\left(8.4 \mu \mathrm{g} \mathrm{m}^{-3}\right)$. These patterns correspond to $\mathrm{OA}$ and sulfate seasonal trends, suggesting the important roles of these species to total NR-PM 1 mass at urban and rural sites across the southeastern US (Tanner et al., 2015; Xu et al., 2015a).

\subsection{Submicron aerosol chemical composition}

At the LRK site, average OA loadings increased from spring $\left(3.2 \mu \mathrm{g} \mathrm{m}^{-3}\right)$ to summer $\left(5.3 \mu \mathrm{g} \mathrm{m}^{-3}\right)$, and then decreased in fall $\left(2.8 \mu \mathrm{g} \mathrm{m}^{-3}\right)$, which is likely related to BVOC emissions that depend on leaf surface area, solar radiation and ambient temperature (Fig. 2; Guenther et al., 2006). A different pattern was observed at the urban site (Fig. 1), where average OA loadings were highest during the fall $\left(8.2 \mu \mathrm{g} \mathrm{m}^{-3}\right)$ followed by winter $\left(7.2 \mu \mathrm{g} \mathrm{m}^{-3}\right)$, suggesting contributions from biomass-burning-related OA and non-biogenic sources. High concentration of OA in fall is slightly lower than ACSM measurement in fall 2011 (Budisulistiorini et al., 2013), but consistent with HR-ToF-AMS measurements in November 2012 (Xu et al., 2015a; Table S4), suggesting the role of meteo- 
Table 2. Seasonal averaged mass concentrations of non-refractory $\mathrm{PM}_{1}\left(\mathrm{NR}-\mathrm{PM}_{1}\right)$ in $\mu \mathrm{g} \mathrm{m}{ }^{-3}$, percent contributions of organic and inorganic species measured by the Aerodyne ACSM and PMF factors resolved from Atlanta, GA (JST site), and Look Rock, TN (LRK site), during 2012 and 2013.

\begin{tabular}{|c|c|c|c|c|c|c|c|c|}
\hline & \multicolumn{2}{|c|}{ Winter } & \multicolumn{2}{|c|}{ Spring } & \multicolumn{2}{|c|}{ Summer } & \multicolumn{2}{|c|}{ Fall } \\
\hline & JST & LRK & JST & LRK & JST & LRK & JST & LRK \\
\hline NR-PM 1 & $10.50 \pm 7.32$ & $4.77 \pm 3.32$ & $6.19 \pm 2.85$ & $5.59 \pm 3.47$ & $8.78 \pm 4.46$ & $8.39 \pm 4.44$ & $12.47 \pm 6.72$ & $4.55 \pm 2.55$ \\
\hline $\mathrm{OA}$ & $69.0 \%$ & $50.2 \%$ & $75.9 \%$ & $57.8 \%$ & $70.0 \%$ & $63.4 \%$ & $65.9 \%$ & $62.1 \%$ \\
\hline $\mathrm{SO}_{4}^{2-}$ & $13.4 \%$ & $30.6 \%$ & $12.0 \%$ & $26.9 \%$ & $17.4 \%$ & $24.5 \%$ & $15.8 \%$ & $21.6 \%$ \\
\hline $\mathrm{NO}_{3}^{-}$ & $9.3 \%$ & $9.2 \%$ & $5.6 \%$ & $6.1 \%$ & $4.5 \%$ & $3.8 \%$ & $9.3 \%$ & $7.2 \%$ \\
\hline $\mathrm{NH}_{4}^{+}$ & $7.9 \%$ & $9.9 \%$ & $6.3 \%$ & $9.0 \%$ & $7.9 \%$ & $8.2 \%$ & $8.6 \%$ & $9.1 \%$ \\
\hline $\mathrm{Cl}^{-}$ & $0.3 \%$ & $0.1 \%$ & $0.2 \%$ & $0.1 \%$ & $0.1 \%$ & $0.1 \%$ & $0.3 \%$ & $0.0 \%$ \\
\hline \multicolumn{9}{|c|}{ OA speciation } \\
\hline HOA & $24 \%$ & n.a. & $20 \%$ & n.a. & $18 \%$ & n.a. & $20 \%$ & n.a. \\
\hline BBOA & $19 \%$ & $33 \%$ & n.a. & n.a. & n.a. & n.a. & $15 \%$ & n.a. \\
\hline SV-OOA & $26 \%$ & n.a. & n.a. & n.a. & n.a. & n.a. & $28 \%$ & n.a. \\
\hline LV-OOA & $30 \%$ & $66 \%$ & $43 \%$ & $37 \%$ & $44 \%$ & $36 \%$ & $37 \%$ & $63 \%$ \\
\hline $91 \mathrm{Fac}$ & n.a. & n.a. & n.a. & $21 \%$ & n.a. & $23 \%$ & n.a. & $9 \%$ \\
\hline IEPOX-OA & n.a. & n.a. & $37 \%$ & $41 \%$ & $38 \%$ & $40 \%$ & n.a. & $27 \%$ \\
\hline Residuals & $1 \%$ & $1 \%$ & $0 \%$ & $1 \%$ & $0 \%$ & $1 \%$ & $0 \%$ & $1 \%$ \\
\hline
\end{tabular}

n.a. denotes values not available or resolved from PMF analysis. PMF analysis yielded some residuals of unresolved OA mass that make up the remaining percentage of OA factors.

rology. Average OA contributions to NR-PM 1 were higher in spring and summer at JST and LRK, suggesting that biogenic SOA plays a significant role during these periods. OA characterization is further discussed in Sect. 3.2.

Average sulfate concentrations were highest in summer for LRK $\left(2.1 \mu \mathrm{g} \mathrm{m}^{-3}\right)$ and fall for JST $\left(\sim 2 \mu \mathrm{g} \mathrm{m}^{-3}\right.$; Fig. 3). This suggests that sulfate may contribute to enhanced SOA formation in this region (Lin et al., 2013a; Xu et al., 2015b; Budisulistiorini et al., 2015). Changes in sulfate concentration at LRK were mainly affected by changes in $\mathrm{SO}_{2}$ emissions from electrical-generating units in the region (Tanner et al., 2015). At JST, sulfate measurements are lower but still within a standard deviation of those measured by HR-ToFAMS in May and July 2012 in Atlanta (Xu et al., 2015a). SO $_{2}$ emissions from coal-fired power plants nearby Atlanta contributed to spatial variability of sulfate concentration (Peltier et al., 2007). The average contribution of sulfate to NR-PM 1 loading was quite significant throughout the year, ranging from 12 to $17 \%$ at JST and from 21 to $31 \%$ at LRK (Table 2). Average concentrations of ammonium and nitrate were $<1$ JST and $<0.5 \mu \mathrm{g} \mathrm{m}^{-3}$ at LRK. The average ammonium and nitrate contribution to seasonal average NR-PM $\mathrm{PM}_{1}$ loadings is small compared to OA and sulfate (Table 2). Both ammonium and nitrate showed similar trends at the JST site, where they were highest during colder seasons (winter and fall), while showing no significant fluctuations during the duration of the study at LRK. This observation is consistent with previous studies (Tanner et al., 2004b; Olszyna et al., 2005) reporting that average contributions of ammonium and nitrate are not significant for rural $\mathrm{PM}_{1}$. Average non-refractory chloride loadings were low $\left(<0.1 \mu \mathrm{g} \mathrm{m}^{-3}\right)$, indicating that it is not a significant contributor to inorganic aerosol mass in this region. The increasing average contributions from the sum of sulfate, ammonium and nitrate in winter and fall at JST suggests the important role of inorganics in NR-PM , in $^{2}$ accord with observations in other major urban areas (Sun et al., 2011; Petit et al., 2015).

The lowest seasonal average $\mathrm{pH}$ was observed in summer (1.45) for JST (Fig. 3) and in fall (1.53) for LRK (Fig. 3). On the other hand, the highest seasonal average $\mathrm{pH}$ was 2.01 for JST and 1.81 for LRK, which were observed during winter. Overall, seasonal aerosol $\mathrm{pH}$ was $1.5-2.0$ at both sites, indicating that NR-PM 1 in the southeastern US is acidic year round. This is consistent with a recent study by Guo et al. (2015). No direct correlation $\left(r^{2}<0.1\right)$ was observed between aerosol $\mathrm{pH}$ and $\mathrm{OA}$ at both sites. However, this does not necessarily rule out the potential role of aerosol acidity in enhancing SOA formation in light of laboratory studies, demonstrating a significant $\mathrm{pH}$ effect (Gao et al., 2004; Surratt et al., 2007; Lin et al., 2013b). Uncertainty of aerosol acidity estimation by ISORROPIA-II by omission of organic sulfate as input (Lin et al., 2014) could lead to underprediction of aerosol acidity and the observed lack of correlation with OA. Seasonal averages of LWC were highest during summer at both JST $\left(33.97 \mathrm{~mol} \mathrm{~L}^{-1}\right.$ of aerosol) and LRK $\left(38.17 \mathrm{~mol} \mathrm{~L}^{-1}\right)$ sites. It should be noted that the possible LWC contributions from OA are not included because the organic hygroscopicity parameter estimated from observed cloud condensation nuclei activities of OA (Guo et al., 2015) was not available in this study. Studies have suggested that 

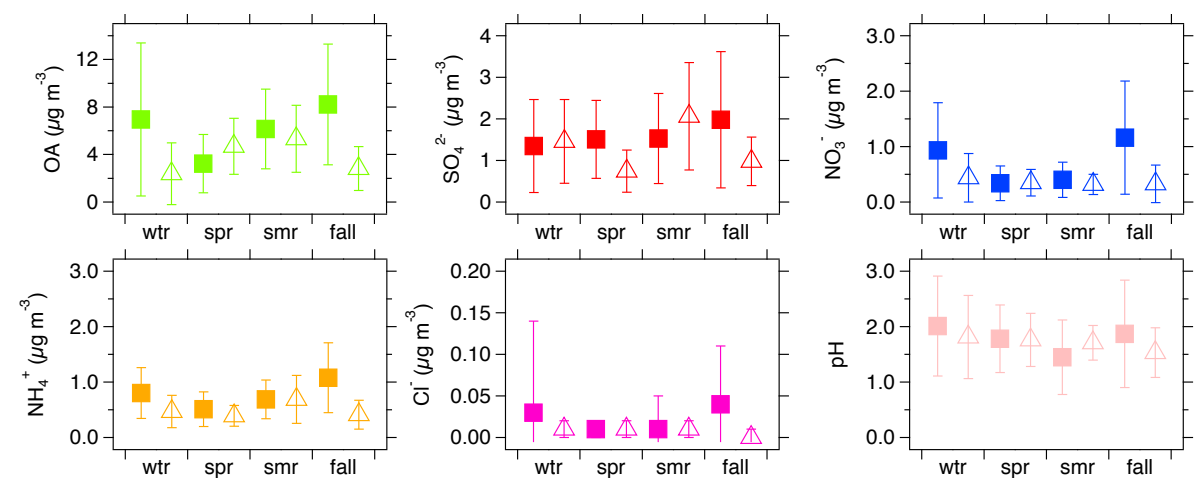

Figure 3. Seasonal averages of OA, inorganic species and $\mathrm{pH}$ from JST (solid squares) and LRK (open triangles). Error bars show \pm 1 standard deviation. Seasons are classified into winter (wtr), spring (spr), summer (smr) and fall.

reactive uptake decreases with enhanced RH (Nguyen et al., 2014; Gaston et al., 2014); however, some isoprene-derived SOA tracers were elevated by high RH (Zhang et al., 2011). Although organic water fraction in total LWC was found to be significant, Guo et al. (2015) suggested that $\mathrm{pH}$ prediction using ISORROPIA-II based on inorganic ions alone gave a reasonable estimate. The lack of correlation between $\mathrm{OA}$ and $\mathrm{pH}$ as well as LWC indicates that $\mathrm{pH}$ and LWC might not be limiting factors in OA production in this region, consistent with previous studies in Georgia and Alabama (Xu et al., 2015a) and Tennessee (Budisulistiorini et al., 2015). It should be noted that this study did not include the contribution of organic water into $\mathrm{pH}$ estimation, which could contribute to the relationship between $\mathrm{pH}$ and $\mathrm{OA}$.

\subsection{OA characterizations}

The mass spectra and time series of OA factors resolved from PMF analysis at JST in 2012 are provided in Figs. 4 and 5, respectively, and at LRK in 2013 are provided in Figs. 6 and 7, respectively. More PMF factors were resolved from JST OA than from LRK OA, which could be due to a larger number of OA source types in urban areas. Each factor had a distinctive time trend throughout 2012 (Fig. 5) at JST and 2013 at LRK (Fig. 7). OA measured at JST in 2012 and LRK in 2013 was composed primarily of low-volatility oxygenated OA (LV-OOA) and IEPOXderived OA factor (IEPOX-OA). Concentrations of LV-OOA and IEPOX-OA at both sites were 1.9 and $1.6 \mu \mathrm{g} \mathrm{m}^{-3}$ on average, respectively (Fig. 8). Hydrocarbon-like OA (HOA) and semi-volatile oxygenated OA (SV-OOA) concentrations varied between 1 and $2 \mu \mathrm{g} \mathrm{m}^{-3}$ at JST and biomass burning OA (BBOA) was $\sim 1 \mu \mathrm{g} \mathrm{m}^{-3}$ at both sites. A biogenically influenced factor (91Fac) was observed only at LRK and accounted for $\sim 1 \mu \mathrm{g} \mathrm{m}^{-3}$. Due to a lack of measurements, the potential role of planetary boundary layer (PBL) height to diurnal variation of PMF factors was not accounted for in this study. However, diurnal PBL dynamics or loss processes (e.g. deposition) could influence diurnal patterns observed here for the PMF factors.

\subsubsection{Winter}

PMF analysis of winter OA yielded a four-factor solution at JST (Figs. 4a and 5a) and a two-factor solution at LRK (Figs. 6a and 7a). HOA, BBOA, SV-OOA and low-volatility oxygenated OA (LV-OOA) factors ( $\mathrm{Ng}$ et al., 2011a) were resolved from the JST data set, whereas only the BBOA and LV-OOA factors were resolved from the LRK data set. Increasing the number of factors in PMF analysis of LRK data resulted in splitting factors that share similarities with BBOA factor. Thus, we selected a two-factor solution $(p=2)$ for LRK in winter.

The temporal variation of the HOA factor correlates well $\left(r^{2}>0.7\right)$ with black carbon (BC), carbon monoxide (CO) and reactive nitrogen species $\left(\mathrm{NO}_{y}\right.$; Table S2). Moreover, its diurnal variation (Fig. 9) showed a morning peak, consistent with an expected contribution from vehicular emissions (Zhang et al., 2007).

The BBOA factor concentration increased during the night and decreased during the day at JST (Fig. 9), which could be related to residential and non-residential wood burning as well as PBL dynamics. BBOA at the LRK site also showed a large nighttime peak with a gradual decrease during the day (Fig. 10). The large peak appears to result from a short period of intense biomass burning that occurred during 1518 March 2013. Since a source for this event could not be identified, we do not report it specifically in this study. The time series of BBOA showed low to moderate correlation $\left(r^{2}\right.$ $0.4-0.5$ at JST and $r^{2} 0.2-0.4$ at LRK) with BC, suggesting that it is likely influenced by some local sources (e.g., fires). BBOA mass spectra from JST and LRK were highly correlated $\left(r^{2} \sim 0.7\right)$, indicating similarity of the sources. Comparison of the BBOA mass spectra with reference mass spectra showed correlation with other OOA factors (Tables S2 and S3), a known caveat in resolution of BBOA based on unit mass resolution (UMR) data such as those from ACSM 

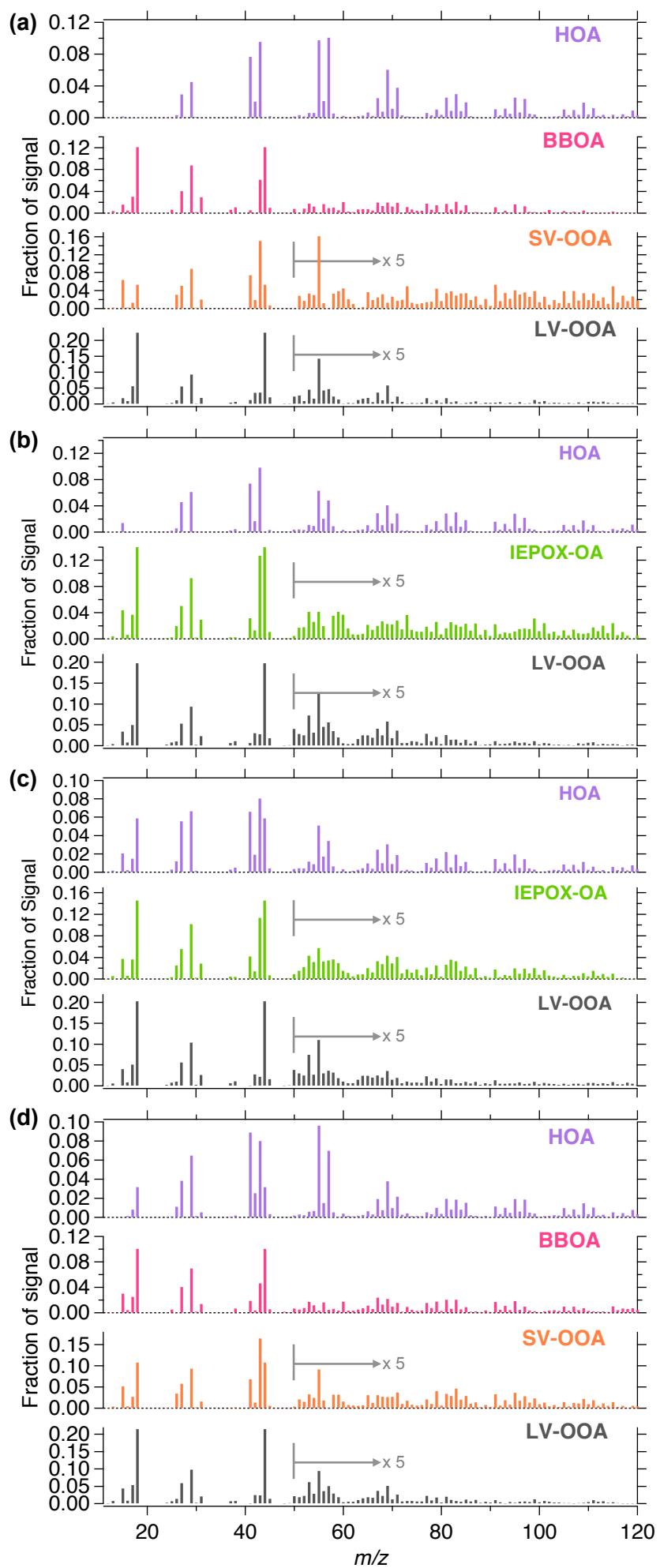

Figure 4. Mass spectra of PMF factors resolved from (a) winter, (b) spring, (c) summer and (d) fall OA measured at JST in 2012. 


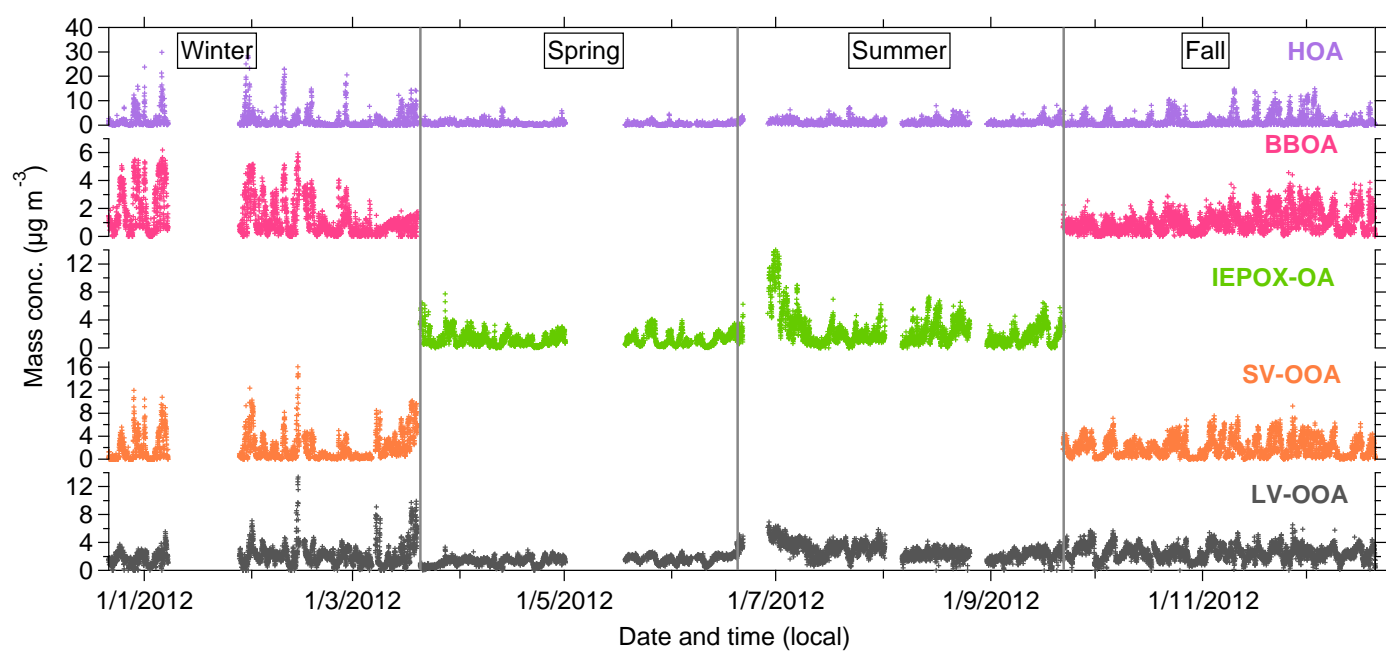

Figure 5. Annual temporal variation of PMF factors resolved from OA measured at JST in 2012.

Thus, BBOA and/or HOA were not resolved from LRK in spring.

The average concentration of HOA in Atlanta was lower in spring $\left(0.7 \mu \mathrm{g} \mathrm{m}^{-3}\right)$ than in winter $\left(1.7 \mu \mathrm{g} \mathrm{m}^{-3}\right)$, which could be influenced by dilution - from a rise of the PBL - and evaporation of POA during warmer conditions (Robinson et al., 2007). Although its concentration decreases, the diurnal pattern of HOA was consistent from winter to spring (Fig. 9) and correlation with primary species was strong $\left(r^{2} \sim 0.6\right.$, Table S2).

Average LV-OOA concentration at JST also was the lowest in spring $\left(1.4 \mu \mathrm{g} \mathrm{m}^{-3}\right)$, which might be attributed to warming temperatures that elevate the PBL and enhance atmospheric mixing. Diurnal variation of LRK LV-OOA (Fig. 10) showed a small diurnal maximum in the afternoon, whereas no variation was observed for JST LV-OOA (Fig. 9). LRK LV-OOA showed moderate correlation with sulfate $\left(r^{2}>0.4\right.$, Table S3), suggesting influence of sulfate at this site during spring (Tanner et al., 2015). Although no correlation was found for JST LV-OOA vs. sulfate, comparison of mass spectra revealed the same strong correlation $\left(r^{2} \sim 1\right.$, Fig. S25) between JST and LRK LV-OOA factors observed in winter, suggesting possible similar sources over a regional scale.

The IEPOX-OA factor, attributed to IEPOX heterogeneous chemistry (Budisulistiorini et al., 2013; Lin et al., 2012), was resolved from data sets at both JST and LRK. It was the second most abundant OA type after LV-OOA at JST, but the most abundant OA component at LRK (Table 2). The average IEPOX-OA concentration was slightly higher at LRK than at JST, which is expected due to abundant emissions of isoprene at the forested site. Diurnal patterns of IEPOX-OA are different at JST and LRK. At LRK, IEPOX-OA has insignificant diurnal variability, which is likely influenced by small variability of sulfate as previously observed at this site (Tanner et al., 2005). However, a small increase in the afternoon and constant concentration until the evening suggests that this factor is driven by photooxidation of isoprene (Budisulistiorini et al., 2013). At JST, the diurnal pattern of IEPOX-OA followed that of total OA, where it slightly decreased during the day before it increased again in the evening. This diurnal pattern is different from previous observations at JST during summer 2011 (Budisulistiorini et al., 2013), but quite similar to isoprene OA from May 2012 reported by Xu et al. (2015a), suggesting influence of year-to-year changes in meteorology, such as precipitation and solar radiation (Table S1). Nevertheless, the mass spectra of IEPOX-OA at JST and LRK are tightly correlated $\left(r^{2} \sim 1\right)$, indicative of similar composition.

91Fac was resolved only at the LRK site and accounted for $0.7-1.2 \mu \mathrm{g} \mathrm{m}^{-3}$. 91Fac has been attributed to various sources: monoterpenes-derived SOA (Budisulistiorini et al., 2015; Boyd et al., 2015), biogenic SOA (Chen et al., 2015) and aged BBOA (Robinson et al., 2011). However, a recent field study identified ions at $m / z 18,29$ and 44 as markers for aged BBOA but not $\mathrm{m} / \mathrm{z} 91$ ion (Bougiatioti et al., 2014). Since BBOA was not resolved from OA measurements in spring, aging of BBOA seems unlikely to be the source of 91Fac in this study, although it cannot be conclusively ruled out. The lack of 91Fac at the JST site suggests that its sources may be limited to emissions and chemical processes in forested and/or rural areas. 91Fac will be further discussed in Sect. 4.2.

\subsubsection{Summer}

PMF analysis of summer OA resolved the same factors as spring at both sites: HOA, LV-OOA and IEPOX-OA factors at JST (Figs. 4c and 5c), and LV-OOA, 91Fac and IEPOXOA factors at LRK (Figs. 6c and 7c). Average HOA mass concentration at JST increased in summer to $\sim 1.1 \mu \mathrm{g} \mathrm{m}^{-3}$ (Fig. 8). Temporal variation of HOA was well correlated $\left(r^{2} \sim 0.6\right)$ with $\mathrm{BC}, \mathrm{CO}$ and $\mathrm{NO}_{x}$ (Table S2) and the diur- 

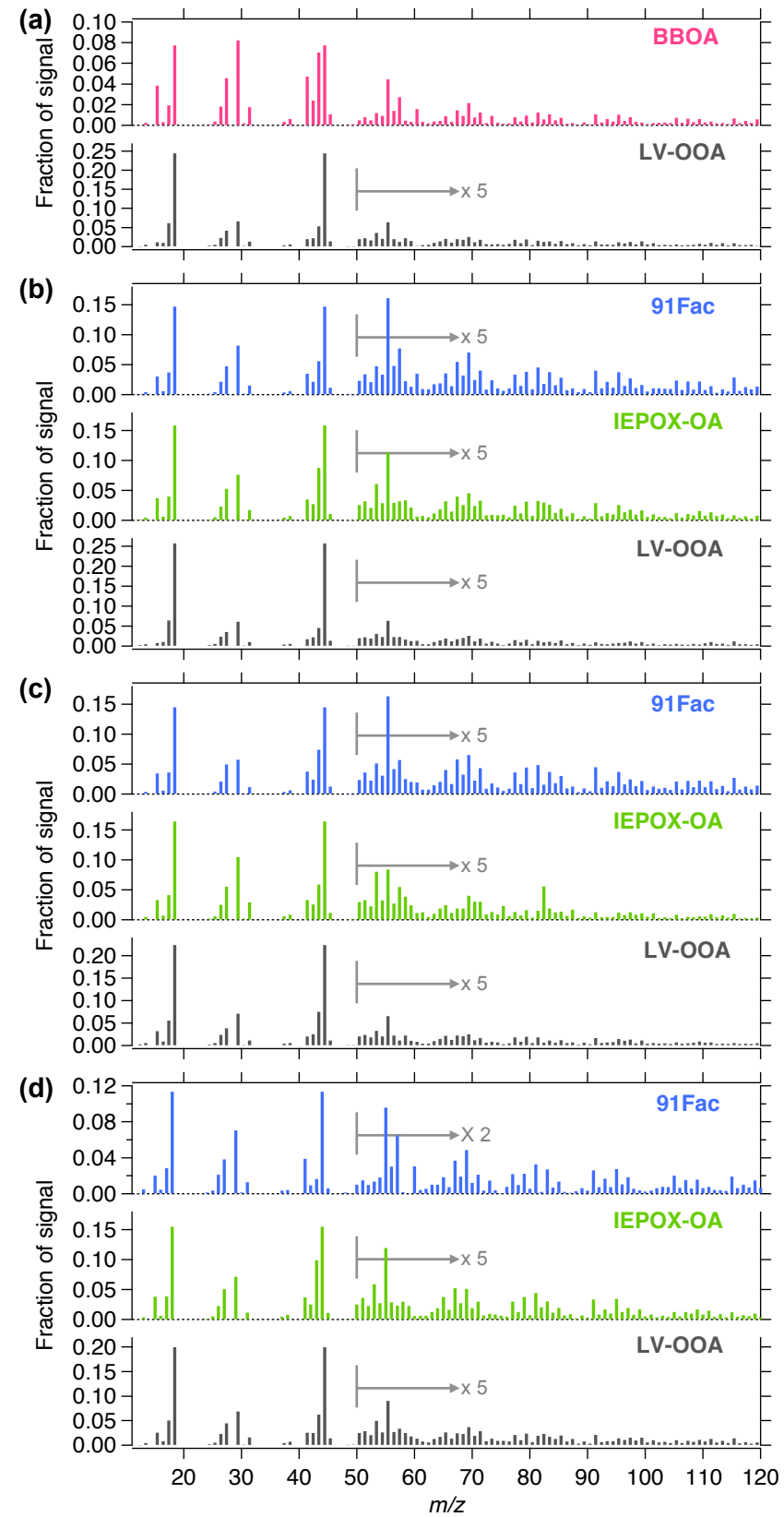

bles S2-S3). The diurnal profile of LRK LV-OOA showed a local maximum in mid-afternoon (Fig. 10) and has a moderate correlation $\left(r^{2} \sim 0.4\right)$ with the sulfate (Table S3), suggesting that sulfate plays a role in LV-OOA in summer at LRK. Comparison of JST and LRK LV-OOA mass spectra revealed a strong correlation $\left(r^{2}=0.94\right)$, possibly suggesting similar sources between two sites.

Average concentration of the 91Fac OA at LRK was higher in summer than spring, which indicates the role of meteorology - an increasing temperature from $\sim 13^{\circ} \mathrm{C}$ in spring to $\sim 21^{\circ} \mathrm{C}$ in summer (Table S1). The relative contribution of 91Fac to total OA increased at LRK (Table 2) and its diurnal profile showed a local maximum around noon. A moderate correlation of $91 \mathrm{Fac}$ with nitrate $\left(r^{2} \sim 0.5\right.$, Table S3) suggests that the factor is moderately oxidized.

Average concentration of IEPOX-OA at JST and LRK increased during summer. At LRK, the average concentration of IEPOX-OA reached a maximum in summer, but its relative contribution to total OA mass was lower due to the increasing concentration of 91Fac. Concentrations of IEPOX-OA at both sites are comparable (Fig. 8), suggesting that in summer this factor may become spatially homogeneous in the southeastern US. Since measurements at JST and LRK were conducted during different years, meteorological changes might play a role in site-to-site comparison. At LRK, IEPOX-OA showed a small increase around noon, while at JST there was a local maximum in the mid-afternoon, suggesting an influx of IEPOX-OA likely transported from surrounding forested areas. The time series of IEPOX-OA was moderately correlated with nitrate $\left(r^{2} \sim 0.4\right)$ at JST, and at LRK, stronger correlations $\left(r^{2}>0.5\right)$ with sulfate and nitrate were observed, suggesting that this factor is moderately oxidized.

\subsubsection{Fall}

At JST, PMF analysis of fall OA resulted in a four-factor solution (i.e., HOA, BBOA, SV-OOA and LV-OOA), while at LRK a three-factor solution was resolved (i.e., LV-OOA, 91Fac and IEPOX-OA). Increasing the number of factors in PMF analysis of JST fall data resulted in factor splitting, and thus, the IEPOX-OA factor was not resolved from this data set. Similarly, we could not resolve the BBOA factor from LRK fall data because the analysis resulted in splitting components.

The concentration of JST HOA increased to a level comnal pattern was similar to that of spring (Fig. 9). Similar to spring, SV-OOA was not resolved in summer, which could be attributed to rapid evaporation of semi-volatile species under high ambient temperatures (Table S1).

Average LV-OOA concentrations at both sites increased in summer; however, the proportional contribution decreased as a result of a larger contribution of IEPOX-OA at JST and 91Fac at LRK (Table 2). The time series of LV-OOA was weakly correlated with sulfate $\left(r^{2} \sim 0.2\right)$ at JST, but more strongly correlated with sulfate at LRK $\left(r^{2}=0.6-0.7\right.$; Taparable to that in winter (Fig. 5), which might be influenced by meteorology - a low ambient temperature and less solar radiation - in fall and winter. The correlation of the time series of HOA with $\mathrm{BC}, \mathrm{CO}$ and $\mathrm{NO}_{x}\left(r^{2}>0.7\right)$ was similar to spring and summer and slightly stronger than in winter (Table S2) and the diurnal profile appears similar to that in winter (Fig. 9). The presence of the HOA factor throughout the year at JST is expected due to traffic emissions in urban areas (Xu et al., 2015a). 


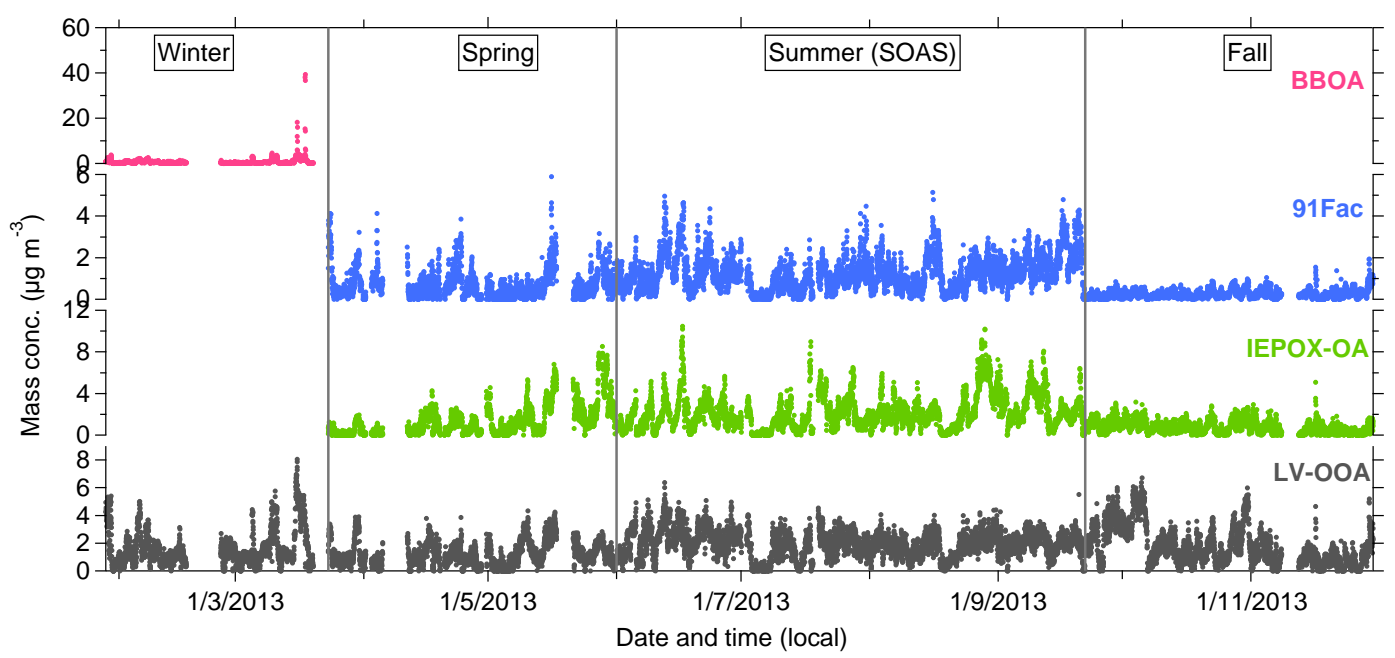

Figure 7. Annual temporal variation of PMF factors resolved from OA measured at LRK in 2013. OA measurements in the summer included results from the Southern Oxidant Aerosol Study (SOAS) campaign that have been published in Budisulistiorini et al. (2015).
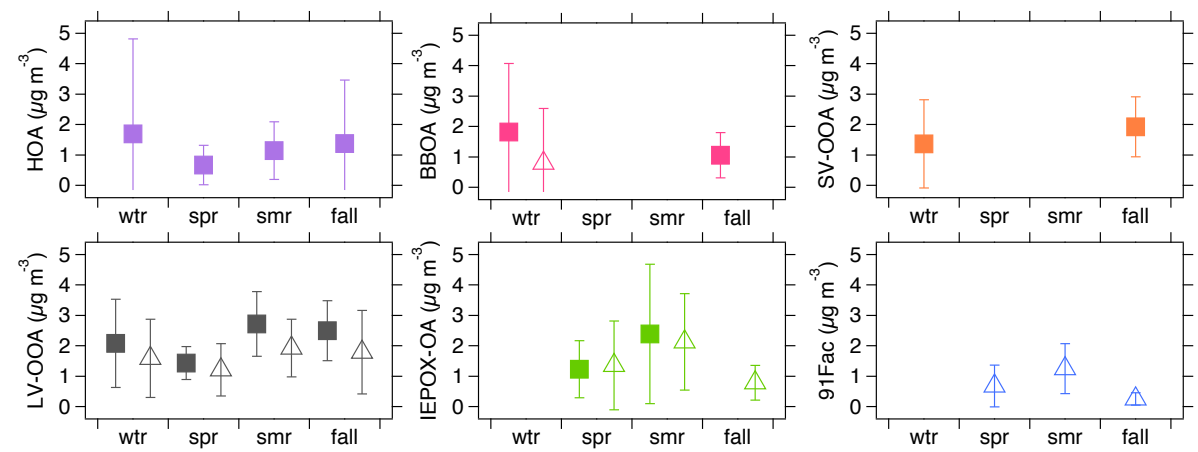

Figure 8. Seasonal average mass concentrations of PMF factors resolved from JST (solid squares) and LRK (open triangles). Error bars are shown as \pm 1 standard deviation.

At JST, the BBOA factor was resolved again from OA with average concentration and fractional contribution to total OA less than observed in winter. The diurnal profile of BBOA during fall at JST appeared similar to that in winter, suggesting similar emission sources as well as possible PBL effect during these two colder seasons. The lack of the BBOA factor at LRK could be attributed to the inability of the ACSM to capture a factor with low concentration. In winter, the ACSM could capture the strong signal of BBOA due to some periods of intense burning which would not be expected in fall.

SV-OOA was also resolved from JST OA with slightly higher average concentration and fractional contribution than that observed in winter. The diurnal profile of fall SV-OOA was similar to that in winter, suggesting similar sources and the role of the PBL. The return of SV-OOA might be influenced by decreases in temperature from $\sim 26^{\circ} \mathrm{C}$ in summer to $\sim 15^{\circ} \mathrm{C}$ in fall (Table S1), resulting in less evaporation of semi-volatile species.

LV-OOA was resolved from OA at both JST and LRK. Average concentrations of LV-OOA remained relatively con- stant from summer to fall at both the urban and rural sites (Fig. 8). However, the contribution of LV-OOA to total OA at LRK increased due to decreasing concentrations of other OA factors (i.e., IEPOX-OA and 91Fac; Table 2). JST LV-OOA did not show diurnal variation, whereas Xu et al. (2015a) observed a small diurnal variation by HR-ToF-AMS. The mass resolution of the ACSM instrument is not as high as the HRToF-AMS; thus, it might not be able to capture the diurnal variability. LRK LV-OOA increased in mid-morning and reached a maximum around mid-afternoon. Temporal variation of LV-OOA was weakly correlated $\left(r^{2} \sim 0.2\right)$ with inorganics at JST, but moderately correlated $\left(r^{2}=0.4-0.5\right)$ at LRK. Strong correlation of LV-OOA mass spectra $\left(r^{2} \sim 1\right.$, slope $=0.8-1.1$, Fig. S25) at JST and LRK indicates a similar or identical source.

The concentration of 91Fac at LRK dropped significantly in fall. The drop coincided with a decrease of total OA concentration and ambient temperature - from around $20^{\circ} \mathrm{C}$ to around $10^{\circ} \mathrm{C}$ (Fig. 2). Temperature has been shown to have a negative effect on SOA formation from monoterpenes 

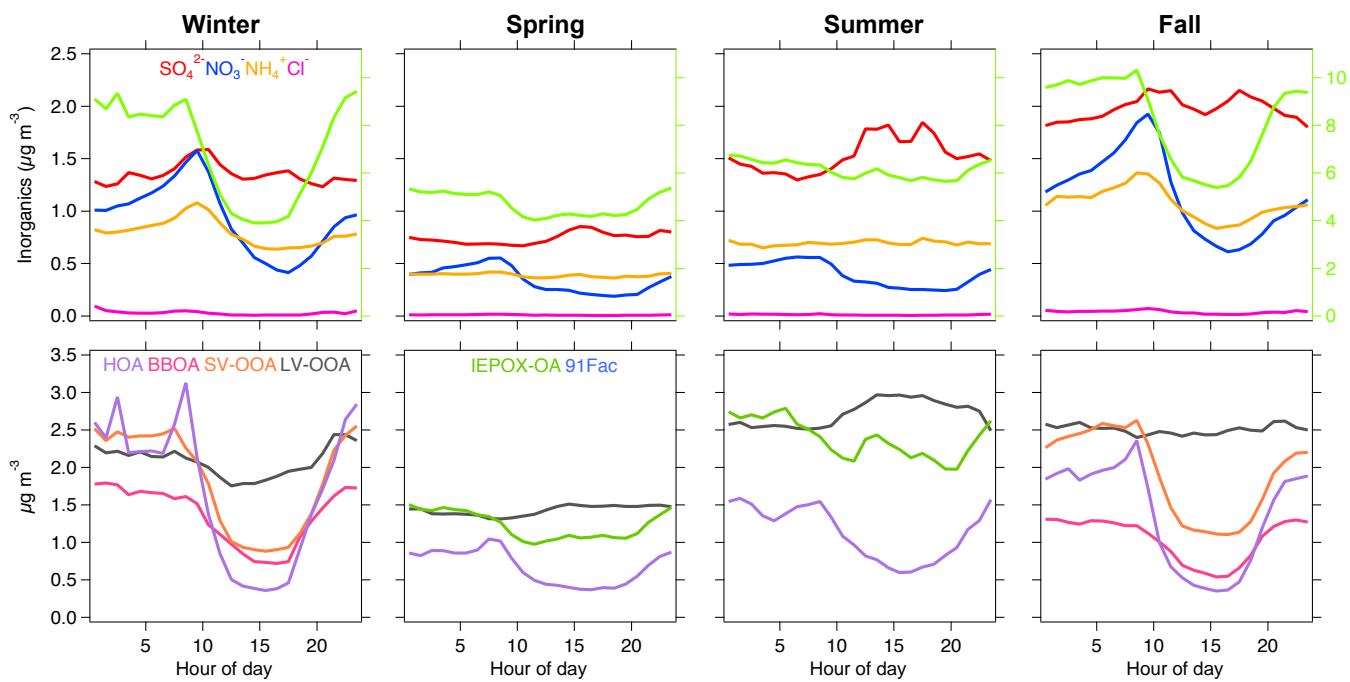

Figure 9. Diurnal variations of OA and inorganic species measured by ACSM (upper panel) and OA factors resolved by PMF analysis (lower panel) from winter, spring, summer and fall measurements at JST in 2012.
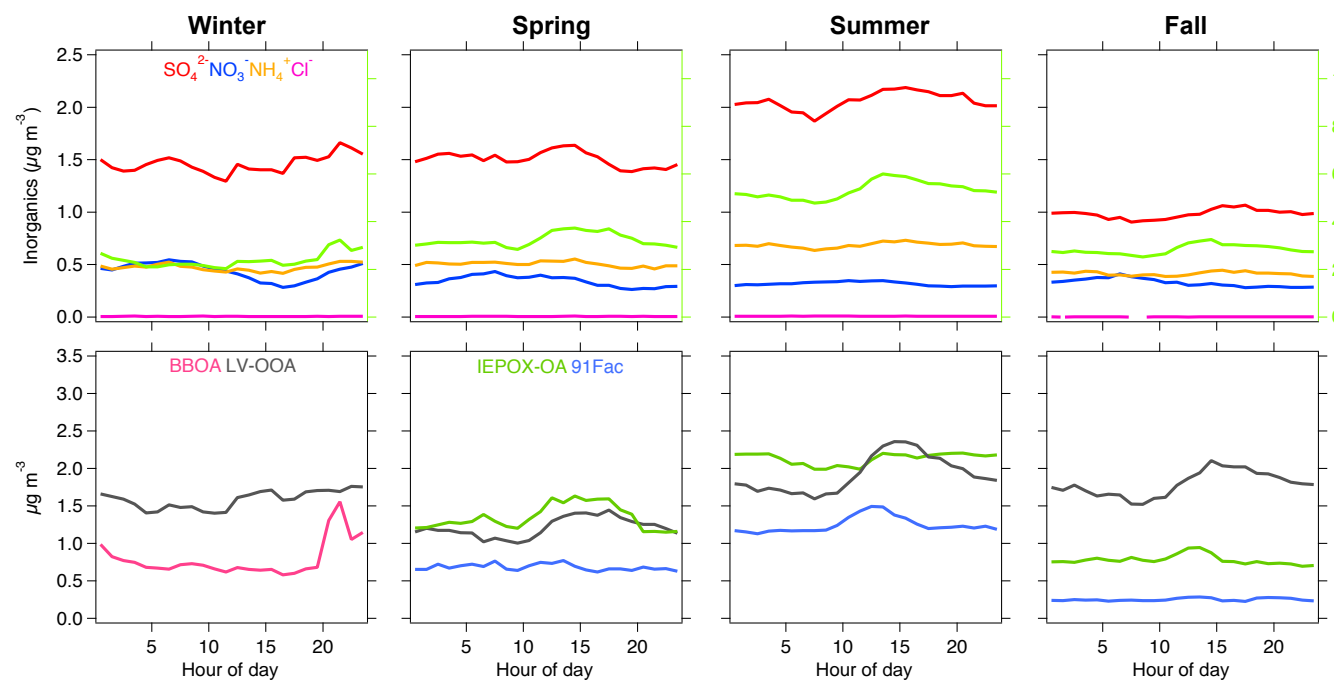

Figure 10. Diurnal variations of OA and inorganic species measured by ACSM (upper panel) and OA factors resolved by PMF analysis (lower panel) from winter, spring, summer and fall measurements at LRK in 2013.

(Emanuelsson et al., 2013), but isoprene SOA is shown to be dependent on temperature (Worton et al., 2013). Similar to 91Fac, IEPOX-OA concentration at LRK also decreased in fall, suggesting that their sources could be similar. The lack of the IEPOX-OA factor at JST is likely due to reduced isoprene emissions, leading to low SOA formation, consistent with previous studies (Budisulistiorini et al., 2013; Xu et al., 2015a).

\subsection{Seasonal changes and contribution of OA sources}

HOA was observed throughout the year at JST in 2012 and contributes significantly to total OA (on average $21 \%$ ), while it was not observed at LRK in 2013. Wider standard devia- tions in winter and fall suggest more variability in HOA mass in Atlanta during these seasons.

LV-OOA, which was also observed throughout the year, contributes $30-43 \%$ of the total OA on average. At LRK, LV-OOA was also observed throughout the year, accounting for a large proportion of total OA in winter, up to $66 \%$. Results from JST and LRK sites suggest that LV-OOA is annually and spatially homogeneous, consistent with previous observations in this region (Xu et al., 2015a).

BBOA was observed during winter and fall 2012 at JST and accounted for $17 \%$ of total OA on average. Standard deviations of mass concentrations indicate large variability of BBOA in winter (Fig. 8), which could be related to increases of biomass burning in urban areas during colder seasons. 


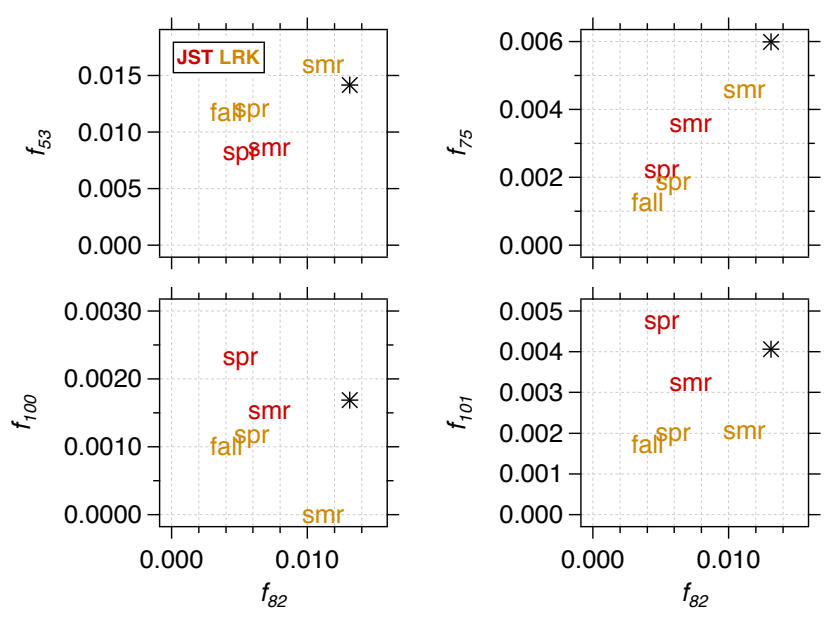

Figure 11. Scatter plots of the $m / z 53$ (possibly $\mathrm{C}_{4} \mathrm{H}_{5}^{+}$), $m / z 75$ (possibly $\mathrm{C}_{3} \mathrm{H}_{7} \mathrm{O}_{2}^{+}$), $m / z, 100$ (possibly $\mathrm{C}_{5} \mathrm{H}_{8} \mathrm{O}_{2}^{+}$) and $\mathrm{m} / z .101$ (possibly $\mathrm{C}_{5} \mathrm{H}_{9} \mathrm{O}_{2}^{+}$) normalized fragment ions from the IEPOXOA mass spectra vs. the $m / z, 82$ normalized fragment ion from the same mass spectra over different seasons at the JST and LRK sites. ACSM measures unit mass resolution (UMR); thus the proposed formulas are based on previous study using HR-ToF-AMS (Lin et al., 2012). The asterisk marker is the respective ion fragments of IEPOX-OA mass spectra resolved from OA measurements during summer 2011 at the JST site (Budisulistiorini et al., 2013).

BBOA was observed only during winter 2013 at LRK. The average concentration of BBOA at LRK was consistently $\sim 1 \mu \mathrm{g} \mathrm{m}^{-3}$, but several episodes of high levels resulted in a large standard deviation (Fig. 8). The LRK site is located quite far from residential areas; thus emissions from residential burning activities might not be well captured by the ACSM during the fall season.

SV-OOA was resolved only at JST and only in the fall and winter, implying that it might be formed from local aging process or transported from nearby areas. SV-OOA contributed $27 \%$ of the total OA on average. During spring and summer, SV-OOA concentrations were probably at or below the ACSM limits of detection due to higher ambient temperatures that likely promote evaporation of semi-volatile species.

IEPOX-OA concentrations were elevated from spring to summer of 2012 at JST and 2013 at LRK in accord with expected enhanced emission and photochemistry of isoprene. In Atlanta (JST), concentration of IEPOX-OA was $38 \%$ of total OA over spring and summer on average. Mass variability of JST IEPOX-OA in summer was large, primarily as a result of a sharp peak in early July, when levels were as high as $\sim 4 \mu \mathrm{g} \mathrm{m}^{-3}$. At LRK, IEPOX-OA was observed in spring, summer and fall seasons with average concentrations of 1.4, 2.1 and $0.8 \mu \mathrm{g} \mathrm{m}^{-3}$ in spring, summer and fall, respectively, contributing $36 \%$ of total OA mass on average. The drastic decrease of IEPOX-OA concentration from summer to fall at LRK (Fig. 7) could be attributed to the drop of ambient temperature that might affect SOA formation (Worton et al., 2013). In addition, significant IEPOX-OA drop is consistent with loss of tree foliage as a major source of isoprene emission, which is supported by a lack of IEPOX-OA during winter.

91Fac factor was observed during spring, summer and fall at LRK in 2013. Seasonal average concentrations of 91Fac were $0.68(21 \%)$ in spring, $1.25(23 \%)$ in summer and $0.25 \mathrm{\mu g} \mathrm{m}^{-3}(9 \%)$ in fall. Further discussion about the possible source(s) of $91 \mathrm{Fac}$ is presented in Sect. 4.2. Decrease of $91 \mathrm{Fac}$ factor from summer to fall (Fig. 7) coincided with decrease total OA and IEPOX-OA factor, possibly suggesting a similar biogenic source.

\section{Discussion}

\subsection{IEPOX-OA factor: fragment ion contributions}

The IEPOX-OA component has been observed in chamber experiments and field OA (Hu et al., 2015). Mass spectra generated by thermal decomposition of isomeric authentic 3-MeTHF and IEPOX standards directly atomized into the Aerodyne HR-ToF-AMS show major fragments at $m / z, 82$ (mostly $\mathrm{C}_{5} \mathrm{H}_{6} \mathrm{O}^{+}$), m/z 53 (mostly $\mathrm{C}_{4} \mathrm{H}_{5}^{+}$) and 75 (mostly $\mathrm{C}_{3} \mathrm{H}_{7} \mathrm{O}_{2}^{+}$, Lin et al., 2012). The ion fragment at $m / z 100$ (mostly $\mathrm{C}_{5} \mathrm{H}_{8} \mathrm{O}_{2}^{+}$) was also suggested as an ion marker for IEPOX-derived SOA (Lin et al., 2013b); however, field studies using ACSM (Budisulistiorini et al., 2013, 2015) showed stronger signal at $m / z 101$ (possibly $\mathrm{C}_{5} \mathrm{H}_{9} \mathrm{O}_{2}^{+}$). Temporal variation of the $m / z 82$ fragment ion associated with LV-OOA, IEPOX-OA and 91Fac (Fig. S26) shows that the IEPOX-OA factor is the predominant contributor to $m / z 82$ at both LRK and JST in spring and summer. During fall the LV-OOA factor becomes a significant contributor to $m / z, 82$ at LRK, which might be due to influence of aged IEPOXOA. Further studies, however, will be needed to examine effects of atmospheric oxidation in IEPOX-OA and LV-OOA mass spectra. The IEPOX-OA mass spectra fragment ions at $m / z 82$ show weak and strong linear relationships with $m / z 53$ and $m / z 75$, respectively and no correlation with $m / z 100$ (Fig. 9). Fractional contribution of ions at $75\left(f_{75}\right)$ vs. the contribution of the ion at $m / z 82\left(f_{82}\right)$ to IEPOX-OA mass spectra show a strong linear relationship $\left(r^{2}=0.95\right.$, slope $=0.49 \pm 0.06$ ) over different locations and seasons, while $f_{53}$ and $f_{82}$ were moderately correlated $\left(r^{2}=0.48\right)$. ACSM mass spectra acquired from the atomization of filter extracts of laboratory-generated IEPOX-derived SOA (Budisulistiorini et al., 2013) and in the IEPOX-OA factor resolved from field studies using the ACSM (Budisulistiorini et al., 2015) gave a quite prominent ion at $m / z 101$ rather than $m / z$ 100. The scatter plots of $f_{101}$ and $f_{100}$ against $f_{82}$ do not show a linear relationship $\left(r^{2}<0.1\right)$, perhaps as a consequence of the low intensity of these ions compared to the other ion fragments. Although parameterizations of the 
Table 3. Correlations of PMF factors resolved from OA measurements at LRK, TN, against SOA tracers from monoterpene chemistry and isoprene ozonolysis quantified during the 2013 SOAS. Some of the monoterpene SOA tracers have been published in Budisulistiorini et al. (2015).

\begin{tabular}{|c|c|c|c|c|}
\hline & IEPOX-OA & LV-OOA & $91 \mathrm{Fac}$ & Ref. \\
\hline \multicolumn{5}{|l|}{ Monoterpene SOA tracers } \\
\hline $\mathrm{C}_{10} \mathrm{H}_{18} \mathrm{O}_{5} \mathrm{~S}$ & 0.28 & 0.26 & 0.39 & Surratt et al. (2008) \\
\hline $\mathrm{C}_{10} \mathrm{H}_{16} \mathrm{O}_{7} \mathrm{~S}^{\mathrm{a}}$ & 0.42 & 0.26 & 0.37 & Surratt et al. (2008) \\
\hline $\mathrm{C}_{10} \mathrm{H}_{17} \mathrm{NO}_{7} \mathrm{~S}$ & 0.00 & 0.00 & 0.01 & Surratt et al. (2008) \\
\hline $\mathrm{C}_{9} \mathrm{H}_{15} \mathrm{NO}_{8} \mathrm{~S}^{\mathrm{a}}$ & 0.12 & 0.22 & 0.22 & Surratt et al. (2008) \\
\hline $\mathrm{C}_{10} \mathrm{H}_{17} \mathrm{NO}_{10} \mathrm{~S}$ & 0.11 & 0.15 & 0.26 & Surratt et al. (2008) \\
\hline $\mathrm{C}_{8} \mathrm{H}_{12} \mathrm{O}_{4}$ (Terpenylic acid) $^{\mathrm{a}}$ & 0.32 & 0.36 & 0.41 & Claeys et al. (2009) \\
\hline $\mathrm{C}_{9} \mathrm{H}_{14} \mathrm{O}_{4}$ (Pinic acid) & 0.12 & 0.21 & 0.19 & \\
\hline $\mathrm{C}_{10} \mathrm{H}_{16} \mathrm{O}_{4}$ (Hydroxy pinonic acid) & 0.15 & 0.21 & 0.25 & \\
\hline $\mathrm{C}_{10} \mathrm{H}_{16} \mathrm{O}_{3}$ (Pinonic acid) & 0.10 & 0.17 & 0.20 & \\
\hline $\mathrm{C}_{7} \mathrm{H}_{10} \mathrm{O}_{4}$ (Terebic acid) & 0.21 & 0.32 & 0.27 & Yasmeen et al. (2010) \\
\hline $\mathrm{C}_{8} \mathrm{H}_{12} \mathrm{O}_{6}(\mathrm{MBTCA})$ & 0.15 & 0.27 & 0.14 & Szmigielski et al. (2007) \\
\hline $\mathrm{C}_{10} \mathrm{H}_{16} \mathrm{O}_{6}$ (DTAA) & 0.35 & 0.42 & 0.42 & Claeys et al. (2009) \\
\hline \multicolumn{5}{|l|}{ Isoprene ozonolysis tracers ${ }^{b}$} \\
\hline $\mathrm{C}_{4} \mathrm{H}_{8} \mathrm{O}_{6} \mathrm{~S}$ & 0.46 & 0.40 & 0.51 & $\begin{array}{l}\text { Safi Shalamzari et al. (2013); } \\
\text { Riva et al. (2015) }\end{array}$ \\
\hline $\mathrm{C}_{5} \mathrm{H}_{12} \mathrm{O}_{6} \mathrm{~S}$ & 0.39 & 0.19 & 0.35 & $\begin{array}{l}\text { Safi Shalamzari et al. (2013); } \\
\text { Riva et al. (2015) }\end{array}$ \\
\hline $\mathrm{C}_{5} \mathrm{H}_{10} \mathrm{O}_{5} \mathrm{~S}$ & 0.19 & 0.19 & 0.22 & Riva et al. (2015) \\
\hline $\mathrm{C}_{5} \mathrm{H}_{10} \mathrm{O}_{6} \mathrm{~S}$ & 0.33 & 0.38 & 0.41 & Riva et al. (2015) \\
\hline $\mathrm{C}_{8} \mathrm{H}_{10} \mathrm{O}_{4} \mathrm{~S}$ & 0.00 & 0.07 & 0.03 & Riva et al. (2015) \\
\hline $\mathrm{C}_{6} \mathrm{H}_{12} \mathrm{O}_{7} \mathrm{~S}$ & 0.24 & 0.33 & 0.48 & Riva et al. (2015) \\
\hline $\mathrm{C}_{9} \mathrm{H}_{14} \mathrm{O}_{6} \mathrm{~S}$ & 0.21 & 0.30 & 0.38 & Riva et al. (2015) \\
\hline $\mathrm{C}_{9} \mathrm{H}_{16} \mathrm{O}_{7} \mathrm{~S}$ & 0.38 & 0.50 & 0.46 & Riva et al. (2015) \\
\hline $\mathrm{C}_{10} \mathrm{H}_{20} \mathrm{O}_{9} \mathrm{~S}$ & 0.36 & 0.29 & 0.39 & Riva et al. (2015) \\
\hline
\end{tabular}

a Published in Budisulistiorini et al. (2015). ${ }^{\mathrm{b}}$ Only nighttime samples were used in PMF factor correlation with isoprene ozonolysis tracers.

IEPOX-OA factor based on its markers (Hu et al., 2015) were not done in this study, this study presents some insights into the role of the $m / z 82$ fragment ion over different seasons in the southeastern US. Observation of the $m / z 75$ fragment ion variation over different seasons indicates its potential as a marker ion for IEPOX-OA detection. Here we have estimated from our field data that the intensity of the ion at $m / z 75$ is about half that of the ion at $m / z 82$ in IEPOX-OA mass spectra. This warrants future study to examine $m / z 75$ ion fragment detection from laboratory-generated IEPOXderived SOA using a higher-resolution aerosol mass spectrometer.

\subsection{Insights into 91Fac OA formation}

Laboratory and field studies have reported significant signal of an $m / z 91$ fragment ion measured by the Aerodyne AMS (e.g., Surratt et al., 2006; Robinson et al., 2011; Slowik et al., 2011; Chen et al., 2015). Surratt et al. (2006) found that this ion strongly correlated with OA mass during isoprene photooxidation under low- $\mathrm{NO}_{x}$ and low- $\mathrm{RH}$ condi- tions in a chamber using ToF-AMS, and proposed $\mathrm{C}_{3} \mathrm{H}_{7} \mathrm{O}_{3}^{+}$ formula for this ion as a tracer for peroxide under low$\mathrm{NO}_{x}$ condition. Field measurements showed that a PMF factor with intense signal at $m / z 91(91 \mathrm{Fac})$ was resolved from OA measurements over densely forested areas where isoprene emissions were dominant and the $\mathrm{NO}_{x}$ level was negligible (Robinson et al., 2011; Budisulistiorini et al., 2015) as well as sites influenced by monoterpene emissions (Slowik et al., 2011). In this study, we found that $\mathrm{NO}_{x}$ is not correlated $\left(r^{2} \sim 0\right)$ with $m / z 91$ of $91 \mathrm{Fac}$ during spring and summer, suggesting that at the LRK site, the factor is not influenced by $\mathrm{NO}_{x}$ (Fig. S27). Correlation values of 0.14 and 0.2 were found between $m / z 91$ ion of 91Fac and $m / z 82$ ion of IEPOX-OA factor during spring and summer, respectively. Since IEPOX-OA is associated with isoprene-derived SOA, the weak correlations indicate that biogenic source(s) - not necessarily isoprene - might contribute to 91Fac formation in densely forested areas like at the LRK site. High-volume $\mathrm{PM}_{2.5}$ filter samples collected at LRK during 1 June-17 July 2013 were analyzed offline for biogenic SOA tracers by ultra performance liquid chro- 
matography/diode array detection-electrospray ionizationhigh-resolution quadrupole time-of-flight mass spectrometry (UPLC/DAD-ESI-HR-QTOFMS; Budisulistiorini et al., 2015). In addition to monoterpene SOA tracers (Surratt et al., 2008; Claeys et al., 2009; Yasmeen et al., 2010; Szmigielski et al., 2007) reported in Budisulistiorini et al. (2015), SOA tracers from isoprene ozonolysis chemistry (Safi Shalamzari et al., 2013; Riva et al., 2015) were also detected (Table 3). Correlations between $91 \mathrm{Fac}$ and SOA tracers from isoprene ozonolysis and monoterpene chemistry are 0.4 and 0.3 on average (Table 3), respectively. These suggest higher potential contributions of isoprene chemistry through a nonIEPOX pathway over monoterpene chemistry in 91Fac formation. Photooxidation of isoprene hydroxy hydroperoxide (ISOPOOH) under low- $\mathrm{NO}_{x}$ conditions was recently shown to yield the formation of low-volatility hydroperoxide compounds (St. Clair et al., 2015), leading to the production of non-IEPOX SOA in chamber and field studies (Krechmer et al., 2015). Further investigations of peroxide contributions to the formation of $91 \mathrm{Fac}$ could not be performed in this study because the details of aerosol-phase tracers and electron ionization fragmentation patterns of non-IEPOX SOA produced from condensation of the low-volatility hydroperoxide compounds are not yet known (St. Clair et al., 2015; Krechmer et al., 2015). This should be a focus of future work. The weak correlations of $91 \mathrm{Fac}$ with monoterpene SOA tracers $\left(r^{2}=0.3\right.$, Table 3$)$ might indicate that multiple sources could contribute to the formation of 91Fac. Laboratory studies found that combined isoprene-, $\alpha$-pinene-, and $\beta$-caryophyllene-derived SOA mass (Chen et al., 2015) as well as $\beta$-pinene $+\mathrm{NO}_{3}$ SOA mass spectra (Boyd et al., 2015) produced an intense signal at $m / z, 91$ associated with $\mathrm{C}_{7} \mathrm{H}_{7}^{+}$. Due to limitation in unit mass resolution of ACSM measurements, we could not identify composition of $m / z 91$ fragment ion. Thus, contributions of $\mathrm{C}_{7} \mathrm{H}_{7}^{+}$and $\mathrm{C}_{3} \mathrm{H}_{7} \mathrm{O}_{3}^{+}$could not be examined in this study.

\section{Conclusions}

Seasonal characterization of NR-PM 1 collected in the southeastern US revealed that OA is the most abundant species, accounting for $50-65 \%$ of total NR-PM 1 at LRK and 65$75 \%$ of total NR-PM 1 at JST. Sulfate is the most abundant inorganic species throughout the year, accounting for 20-30 and $10-20 \%$ of total NR-PM 1 at the rural and urban site, respectively. Nitrate and ammonium followed as the third and fourth most abundant inorganic species, respectively, and were dependent on the season and location. The highest average concentrations of $\mathrm{OA}$, sulfate and ammonium were observed during summer season at LRK and during fall at JST.

Characterization of OA using PMF resolved a combined six factors at JST and LRK sites, with different factors being resolved depending on location, season and year. HOA and SV-OOA were only resolved at JST that represent urban OA.
BBOA, LV-OOA and IEPOX-OA were resolved from both sites during different seasons, while 91Fac was only resolved from LRK site during warmer seasons. HOA contributions to total OA mass were fairly consistent ( $\sim 21 \%$ of total OA) over four seasons, and its contributions peaked during winter. SV-OOA was only observed during colder seasons, having a consistent contribution of $27 \%$ of total OA. BBOA was observed during winter and fall seasons at JST and only during winter at LRK, with the highest contribution of $33 \%$ of total OA observed during winter at the LRK site and $17 \%$ of total OA on average at the JST site. The higher contribution of BBOA at LRK was likely due to a single, significant burning event, whereas contribution at JST is more consistent between winter and fall.

Average IEPOX-OA contributions during warmer seasons were $\sim 38$ and $\sim 41 \%$ of total OA at JST and LRK sites, respectively. While the IEPOX-OA resolved from PMF is characterized by the fragment ion at $m / z 82$, strong correlation of the fractional contributions of the ions $m / z 82$ and 75 fragment ions to IEPOX-OA mass spectra $\left(f_{75}: f_{82} \sim 0.5\right)$ suggests that both ions can serve as markers for IEPOXOA. Average $91 \mathrm{Fac}$ OA contribution was $\sim 22 \%$ of total OA at the LRK site over spring and summer. Based on correlations with SOA tracer analysis performed offline, 91Fac showed an overall higher correlation with SOA markers of isoprene ozonolysis and photooxidation than with monoterpene oxidation. This might indicate that 91Fac at LRK could be influenced by isoprene chemistry, but might have different sources in other locations where isoprene is not in high abundance. The abundance of $91 \mathrm{Fac}$ in isoprene-dominated forested areas such as LRK warrants further study to determine the source, since multiple biogenic sources or lowvolatility hydroperoxide compounds might contribute to this factor.

\section{The Supplement related to this article is available online at doi:10.5194/acp-16-5171-2016-supplement.}

Acknowledgements. This study was supported by the Electric Power Research Institute (EPRI). We thank Jerry Brown of Atmospheric Research and Analysis (ARA) as well as Bill Hicks of the Tennessee Valley Authority (TVA) for their assistance in collecting the collocated monitoring data at the JST and LRK sites, respectively. S. H. Budisulistiorini was supported in part by a Fulbright Presidential Fellowship (2010-2013) for attending the University of North Carolina at Chapel Hill, the UNC Graduate School Off-Campus Dissertation Research Fellowship and EPRI.

Edited by: E. Browne 


\section{References}

Bougiatioti, A., Stavroulas, I., Kostenidou, E., Zarmpas, P., Theodosi, C., Kouvarakis, G., Canonaco, F., Prévôt, A. S. H., Nenes, A., Pandis, S. N., and Mihalopoulos, N.: Processing of biomassburning aerosol in the eastern Mediterranean during summertime, Atmos. Chem. Phys., 14, 479-4807, doi:10.5194/acp-144793-2014, 2014.

Boyd, C. M., Sanchez, J., Xu, L., Eugene, A. J., Nah, T., Tuet, W. Y., Guzman, M. I., and Ng, N. L.: Secondary organic aerosol formation from the $\beta$-pinene $+\mathrm{NO}_{3}$ system: effect of humidity and peroxy radical fate, Atmos. Chem. Phys., 15, 7497-7522, doi:10.5194/acp-15-7497-2015, 2015.

Budisulistiorini, S. H., Canagaratna, M. R., Croteau, P. L., Marth, W. J., Baumann, K., Edgerton, E. S., Shaw, S. L., Knipping, E. M., Worsnop, D. R., Jayne, J. T., Gold, A., and Surratt, J. D.: Real-Time Continuous Characterization of Secondary Organic Aerosol Derived from Isoprene Epoxydiols in Downtown Atlanta, Georgia, Using the Aerodyne Aerosol Chemical Speciation Monitor, Environ. Sci. Technol., 47, 5686-5694, doi:10.1021/es400023n, 2013.

Budisulistiorini, S. H., Canagaratna, M. R., Croteau, P. L., Baumann, K., Edgerton, E. S., Kollman, M. S., Ng, N. L., Verma, V., Shaw, S. L., Knipping, E. M., Worsnop, D. R., Jayne, J. T., Weber, R.J., and Surratt, J. D.: Intercomparison of an Aerosol Chemical Speciation Monitor (ACSM) with ambient fine aerosol measurements in downtown Atlanta, Georgia, Atmos. Meas. Tech., 7, 1929-1941, doi:10.5194/amt-7-1929-2014, 2014.

Budisulistiorini, S. H., Li, X., Bairai, S. T., Renfro, J., Liu, Y., Liu, Y. J., McKinney, K. A., Martin, S. T., McNeill, V. F., Pye, H. O. T., Nenes, A., Neff, M. E., Stone, E. A., Mueller, S., Knote, C., Shaw, S. L., Zhang, Z., Gold, A., and Surratt, J. D.: Examining the effects of anthropogenic emissions on isoprenederived secondary organic aerosol formation during the 2013 Southern Oxidant and Aerosol Study (SOAS) at the Look Rock, Tennessee ground site, Atmos. Chem. Phys., 15, 8871-8888, doi:10.5194/acp-15-8871-2015, 2015.

Butler, A. J., Andrew, M. S., and Russell, A. G.: Daily sampling of $\mathrm{PM}_{2.5}$ in Atlanta: Results of the first year of the Assessment of Spatial Aerosol Composition in Atlanta study, J. Geophys. Res., 108, SOS 3-1-SOS 3-11, doi:10.1029/2002JD002234, 2003.

Chen, Q., Farmer, D. K., Rizzo, L. V., Pauliquevis, T., Kuwata, M., Karl, T. G., Guenther, A., Allan, J. D., Coe, H., Andreae, M. O., Pöschl, U., Jimenez, J. L., Artaxo, P., and Martin, S. T.: Submicron particle mass concentrations and sources in the Amazonian wet season (AMAZE-08), Atmos. Chem. Phys., 15, 3687-3701, doi:10.5194/acp-15-3687-2015, 2015.

Claeys, M., Iinuma, Y., Szmigielski, R., Surratt, J. D., Blockhuys, F., Van Alsenoy, C., Boge, O., Sierau, B., Gómez-González, Y., Vermeylen, R., Van der Veken, P., Shahgholi, M., Chan, A. W. H., Herrmann, H., Seinfeld, J. H., and Maenhaut, W.: Terpenylic Acid and Related Compounds from the Oxidation of $\alpha$-Pinene: Implications for New Particle Formation and Growth above Forests, Environ. Sci. Technol., 43, 6976-6982, doi:10.1021/es9007596, 2009.

Crippa, M., Canonaco, F., Lanz, V. A., Äijälä, M., Allan, J. D., Carbone, S., Capes, G., Ceburnis, D., Dall'Osto, M., Day, D. A., DeCarlo, P. F., Ehn, M., Eriksson, A., Freney, E., Hildebrandt Ruiz, L., Hillamo, R., Jimenez, J. L., Junninen, H., Kiendler-Scharr, A., Kortelainen, A.-M., Kulmala, M., Laaksonen, A., Mensah,
A. A., Mohr, C., Nemitz, E., O’Dowd, C., Ovadnevaite, J., Pandis, S. N., Petäjä, T., Poulain, L., Saarikoski, S., Sellegri, K., Swietlicki, E., Tiitta, P., Worsnop, D. R., Baltensperger, U., and Prévôt, A. S. H.: Organic aerosol components derived from 25 AMS data sets across Europe using a consistent ME-2 based source apportionment approach, Atmos. Chem. Phys., 14, 61596176, doi:10.5194/acp-14-6159-2014, 2014.

Cross, E. S., Slowik, J. G., Davidovits, P., Allan, J. D., Worsnop, D. R., Jayne, J. T., Lewis, D. K., Canagaratna, M., and Onasch, T. B.: Laboratory and Ambient Particle Density Determinations using Light Scattering in Conjunction with Aerosol Mass Spectrometry, Aerosol Sci. Technol., 41, 343-359, doi:10.1080/02786820701199736, 2007.

Docherty, K. S., Stone, E. A., Ulbrich, I. M., DeCarlo, P. F., Snyder, D. C., Schauer, J. J., Peltier, R. E., Weber, R. J., Murphy, S. M., Seinfeld, J. H., Grover, B. D., Eatough, D. J., and Jimenez, J. L.: Apportionment of Primary and Secondary Organic Aerosols in Southern California during the 2005 Study of Organic Aerosols in Riverside (SOAR-1), Environ. Sci. Technol., 42, 7655-7662, doi:10.1021/es8008166, 2008.

Edgerton, E. S., Hartsell, B. E., and Jansen, J. J.: Mercury Speciation in Coal-fired Power Plant Plumes Observed at Three Surface Sites in the Southeastern US, Environ. Sci. Technol., 40, 45634570, doi:10.1021/es0515607, 2006.

Emanuelsson, E. U., Watne, K., Lutz, A., Ljungström, E., and Hallquist, M.: Influence of Humidity, Temperature, and Radicals on the Formation and Thermal Properties of Secondary Organic Aerosol (SOA) from Ozonolysis of $\beta$-Pinene, J. Phys. Chem. A, 117, 10346-10358, doi:10.1021/jp4010218, 2013.

Forster, P., Ramaswamy, V., Artaxo, P., Berntsen, T., Betts, R., Fahey, D. W., Haywood, J., Lean, J., Lowe, D. C., Myhre, G., Nganga, J., Prinn, R., Raga, G., Schulz, M., and Van Dorland, R.: Changes in Atmospheric Constituents and in Radiative Forcing, in: Climate Change 2007: The Physical Science Basis, Contribution of Working Group I to the Fourth Assessment Report of the Intergovernmental Panel on Climate Change, Cambridge University Press, Cambridge, United Kingdom and New York, NY, USA, 2007.

Fountoukis, C. and Nenes, A.: ISORROPIA II: a computationally efficient thermodynamic equilibrium model for $\mathrm{K}^{+}$ $\mathrm{Ca}^{2+}-\mathrm{Mg}^{2+}-\mathrm{NH}_{4}^{+}-\mathrm{Na}^{+}-\mathrm{SO}_{4}^{2-}-\mathrm{NO}_{3}^{-}-\mathrm{Cl}^{-}-\mathrm{H}_{2} \mathrm{O}$ aerosols, Atmos. Chem. Phys., 7, 4639-4659, doi:10.5194/acp-7-4639-2007, 2007.

Gao, S., Ng, N. L., Keywood, M., Varutbangkul, V., Bahreini, R., Nenes, A., He, J., Yoo, K. Y., Beauchamp, J. L., Hodyss, R. P., Flagan, R. C., and Seinfeld, J. H.: Particle Phase Acidity and Oligomer Formation in Secondary Organic Aerosol, Environ. Sci. Technol., 38, 6582-6589, doi:10.1021/es049125k, 2004.

Gaston, C. J., Riedel, T. P., Zhang, Z., Gold, A., Surratt, J. D., and Thornton, J. A.: Reactive Uptake of an Isoprene-Derived Epoxydiol to Submicron Aerosol Particles, Environ. Sci. Technol., 48, 11178-11186, doi:10.1021/es5034266, 2014.

Guha, A., Gentner, D. R., Weber, R. J., Provencal, R., and Goldstein, A. H.: Source apportionment of methane and nitrous oxide in California's San Joaquin Valley at CalNex 2010 via positive matrix factorization, Atmos. Chem. Phys., 15, 12043-12063, doi:10.5194/acp-15-12043-2015, 2015.

Guenther, A., Karl, T., Harley, P., Wiedinmyer, C., Palmer, P. I., and Geron, C.: Estimates of global terrestrial isoprene emissions 
using MEGAN (Model of Emissions of Gases and Aerosols from Nature), Atmos. Chem. Phys., 6, 3181-3210, doi:10.5194/acp-63181-2006, 2006.

Guo, H., Xu, L., Bougiatioti, A., Cerully, K. M., Capps, S. L., Hite Jr., J. R., Carlton, A. G., Lee, S.-H., Bergin, M. H., Ng, N. L., Nenes, A., and Weber, R. J.: Fine-particle water and $\mathrm{pH}$ in the southeastern United States, Atmos. Chem. Phys., 15, 5211-5228, doi:10.5194/acp-15-5211-2015, 2015.

Hallquist, M., Wenger, J. C., Baltensperger, U., Rudich, Y., Simpson, D., Claeys, M., Dommen, J., Donahue, N. M., George, C., Goldstein, A. H., Hamilton, J. F., Herrmann, H., Hoffmann, T., Iinuma, Y., Jang, M., Jenkin, M. E., Jimenez, J. L., Kiendler-Scharr, A., Maenhaut, W., McFiggans, G., Mentel, Th. F., Monod, A., Prévôt, A. S. H., Seinfeld, J. H., Surratt, J. D., Szmigielski, R., and Wildt, J.: The formation, properties and impact of secondary organic aerosol: current and emerging issues, Atmos. Chem. Phys., 9, 5155-5236, doi:10.5194/acp-9-51552009, 2009.

Hansen, D. A., Edgerton, E. S., Hartsell, B. E., Jansen, J. J., Kandasamy, N., Hidy, G. M., and Blanchard, C. L.: The Southeastern Aerosol Research and Characterization Study: Part 1-Overview, JAPCA J. Air Waste Ma., 53, 1460-1471, doi:10.1080/10473289.2003.10466318, 2003.

Hu, W. W., Campuzano-Jost, P., Palm, B. B., Day, D. A., Ortega, A. M., Hayes, P. L., Krechmer, J. E., Chen, Q., Kuwata, M., Liu, Y. J., de Sá, S. S., McKinney, K., Martin, S. T., Hu, M., Budisulistiorini, S. H., Riva, M., Surratt, J. D., St. Clair, J. M., Isaacman-Van Wertz, G., Yee, L. D., Goldstein, A. H., Carbone, S., Brito, J., Artaxo, P., de Gouw, J. A., Koss, A., Wisthaler, A., Mikoviny, T., Karl, T., Kaser, L., Jud, W., Hansel, A., Docherty, K. S., Alexander, M. L., Robinson, N. H., Coe, H., Allan, J. D., Canagaratna, M. R., Paulot, F., and Jimenez, J. L.: Characterization of a real-time tracer for isoprene epoxydiols-derived secondary organic aerosol (IEPOX-SOA) from aerosol mass spectrometer measurements, Atmos. Chem. Phys., 15, 11807-11833, doi:10.5194/acp-15-11807-2015, 2015.

IPCC: Climate Change 2013: The Physical Science Basis, Contribution of Working Group I to the Fifth Assessment Report to the Intergovernmental Panel on Climate Change, Cambridge University Press, Cambridge, United Kingdom and New York, NY, USA, 2013.

Jacobs, M. I., Burke, W. J., and Elrod, M. J.: Kinetics of the reactions of isoprene-derived hydroxynitrates: gas phase epoxide formation and solution phase hydrolysis, Atmos. Chem. Phys., 14, 8933-8946, doi:10.5194/acp-14-8933-2014, 2014.

Jimenez, J. L., Canagaratna, M. R., Donahue, N. M., Prévôt, A. S. H., Zhang, Q., Kroll, J. H., DeCarlo, P. F., Allan, J. D., Coe, H., Ng, N. L., Aiken, A. C., Docherty, K. S., Ulbrich, I. M., Grieshop, A. P., Robinson, A. L., Duplissy, J., Smith, J. D., Wilson, K. R., Lanz, V. A., Hueglin, C., Sun, Y. L., Tian, J., Laaksonen, A., Raatikainen, T., Rautiainen, J., Vaattovaara, P., Ehn, M., Kulmala, M., Tomlinson, J. M., Collins, D. R., Cubison, M. J. E., Dunlea, J., Huffman, J. A., Onasch, T. B., Alfarra, M. R., Williams, P. I., Bower, K., Kondo, Y., Schneider, J., Drewnick, F., Borrmann, S., Weimer, S., Demerjian, K., Salcedo, D., Cottrell, L., Griffin, R., Takami, A., Miyoshi, T., Hatakeyama, S., Shimono, A., Sun, J. Y., Zhang, Y. M., Dzepina, K., Kimmel, J. R., Sueper, D., Jayne, J. T., Herndon, S. C., Trimborn, A. M., Williams, L. R., Wood, E. C., Middlebrook, A. M., Kolb,
C. E., Baltensperger, U., and Worsnop, D. R.: Evolution of Organic Aerosols in the Atmosphere, Science, 326, 1525-1529, doi:10.1126/science.1180353, 2009.

Kanakidou, M., Seinfeld, J. H., Pandis, S. N., Barnes, I., Dentener, F. J., Facchini, M. C., Van Dingenen, R., Ervens, B., Nenes, A., Nielsen, C. J., Swietlicki, E., Putaud, J. P., Balkanski, Y., Fuzzi, S., Horth, J., Moortgat, G. K., Winterhalter, R., Myhre, C. E. L., Tsigaridis, K., Vignati, E., Stephanou, E. G., and Wilson, J.: Organic aerosol and global climate modelling: a review, Atmos. Chem. Phys., 5, 1053-1123, doi:10.5194/acp-5-1053-2005, 2005.

Ke, L., Ding, X., Tanner, R. L., Schauer, J. J., and Zheng, M.: Source contributions to carbonaceous aerosols in the Tennessee Valley Region, Atmos. Environ., 41, 8898-8923, doi:10.1016/j.atmosenv.2007.08.024, 2007.

Kim, E., Hopke, P. K., and Edgerton, E. S.: Source Identification of Atlanta Aerosol by Positive Matrix Factorization, JAPCA J. Air Waste Ma., 53, 731-739, doi:10.1080/10473289.2003.10466209, 2003.

Krechmer, J. E., Coggon, M. M., Massoli, P., Nguyen, T. B., Crounse, J. D., Hu, W., Day, D. A., Tyndall, G. S., Henze, D. K., Rivera-Rios, J., Nowak, J. B., Kimmel, J. R., Mauldin, R. L., Stark, H., Jayne, J. T., Sipila, M., Junninen, H., Clair, J. M. S., Zhang, X., Feiner, P. A., Zhang, L., Miller, D. O., Brune, W. H., Keutsch, F. N., Wennberg, P. O., Seinfeld, J. H., Worsnop, D. R., Jimenez, J. L., and Canagaratna, M. R.: Formation of Low Volatility Organic Compounds and Secondary Organic Aerosol from Isoprene Hydroxyhydroperoxide Low-NO Oxidation, Environ. Sci. Technol., 49, 10330-10339, doi:10.1021/acs.est.5b02031, 2015.

Lanz, V. A., Alfarra, M. R., Baltensperger, U., Buchmann, B., Hueglin, C., and Prévôt, A. S. H.: Source apportionment of submicron organic aerosols at an urban site by factor analytical modelling of aerosol mass spectra, Atmos. Chem. Phys., 7, 15031522, doi:10.5194/acp-7-1503-2007, 2007.

Lee, S., Murphy, D. M., Thomson, D. S., and Middlebrook, A. M.: Chemical components of single particles measured with Particle Analysis by Laser Mass Spectrometry (PALMS) during the Atlanta SuperSite Project: Focus on organic/sulfate, lead, soot, and mineral particles, J. Geophys. Res., 107, 4003-4015, doi:10.1029/2000JD000011, 2002.

Lin, Y., Budisulistiorini, S. H., Chu, K., Siejack, R. A., Zhang, H., Riva, M., Zhang, Z., Gold, A., Kautzman, K. E., and Surratt, J. D.: Light-Absorbing Oligomer Formation in Secondary Organic Aerosol from Reactive Uptake of Isoprene Epoxydiols, Environ. Sci. Technol., 48, 12012-12021, doi:10.1021/es503142b, 2014.

Lin, Y.-H., Knipping, E. M., Edgerton, E. S., Shaw, S. L., and Surratt, J. D.: Investigating the influences of $\mathrm{SO}_{2}$ and $\mathrm{NH}_{3}$ levels on isoprene-derived secondary organic aerosol formation using conditional sampling approaches, Atmos. Chem. Phys., 13, 84578470, doi:10.5194/acp-13-8457-2013, 2013a.

Lin, Y., Zhang, H., Pye, H. O. T., Zhang, Z., Marth, W. J., Park, S., Arashiro, M., Cui, T., Budisulistiorini, S. H., Sexton, K. G., Vizuete, W., Xie, Y., Luecken, D. J., Piletic, I. R., Edney, E. O., Bartolotti, L. J., Gold, A., and Surratt, J. D.: Epoxide as a precursor to secondary organic aerosol formation from isoprene photooxidation in the presence of nitrogen oxides, P. Natl. Acad. Sci USA, 110, 6718-6723, doi:10.1073/pnas.1221150110, $2013 \mathrm{~b}$. 
Lin, Y., Zhang, Z., Docherty, K. S., Zhang, H., Budisulistiorini, S. H., Rubitschun, C. L., Shaw, S. L., Knipping, E. M., Edgerton, E. S., Kleindienst, T. E., Gold, A., and Surratt, J. D.: Isoprene Epoxydiols as Precursors to Secondary Organic Aerosol Formation: Acid-Catalyzed Reactive Uptake Studies with Authentic Compounds, Environ. Sci. Technol., 46, 250258, doi:10.1021/es202554c, 2012.

Nenes, A., Pandis, S. N., and Pilinis, C.: Continued development and testing of a new thermodynamic aerosol module for urban and regional air quality models, Atmos. Environ., 33, 15531560, doi:10.1016/S1352-2310(98)00352-5, 1999.

Ng, N. L., Canagaratna, M. R., Zhang, Q., Jimenez, J. L., Tian, J., Ulbrich, I. M., Kroll, J. H., Docherty, K. S., Chhabra, P. S., Bahreini, R., Murphy, S. M., Seinfeld, J. H., Hildebrandt, L., Donahue, N. M., DeCarlo, P. F., Lanz, V. A., Prévôt, A. S. H., Dinar, E., Rudich, Y., and Worsnop, D. R.: Organic aerosol components observed in Northern Hemispheric datasets from Aerosol Mass Spectrometry, Atmos. Chem. Phys., 10, 46254641, doi:10.5194/acp-10-4625-2010, 2010.

Ng, N. L., Canagaratna, M. R., Jimenez, J. L., Zhang, Q., Ulbrich, I. M., and Worsnop, D. R.: Real-Time Methods for Estimating Organic Component Mass Concentrations from Aerosol Mass Spectrometer Data, Environ. Sci. Technol., 45, 910-916, doi:10.1021/es102951k, 2011a.

Ng, N. L., Herndon, S. C., Trimborn, A., Canagaratna, M. R., Croteau, P. L., Onasch, T. B., Sueper, D., Worsnop, D. R., Zhang, Q., Sun, Y. L., and Jayne, J. T.: An Aerosol Chemical Speciation Monitor (ACSM) for Routine Monitoring of the Composition and Mass Concentrations of Ambient Aerosol, Aerosol Sci. Technol., 45, 780-794, doi:10.1080/02786826.2011.560211, 2011b.

Nguyen, T. B., Coggon, M. M., Bates, K. H., Zhang, X., Schwantes, R. H., Schilling, K. A., Loza, C. L., Flagan, R. C., Wennberg, P. O., and Seinfeld, J. H.: Organic aerosol formation from the reactive uptake of isoprene epoxydiols (IEPOX) onto nonacidified inorganic seeds, Atmos. Chem. Phys., 14, 3497-3510, doi:10.5194/acp-14-3497-2014, 2014.

Olszyna, K. J., Bairai, S. T., and Tanner, R. L.: Effect of ambient $\mathrm{NH}_{3}$ levels on $\mathrm{PM}_{2.5}$ composition in the Great Smoky Mountains National Park, Atmos. Environ., 39, 4593-4606, doi:10.1016/j.atmosenv.2005.04.011, 2005.

Paatero, P. and Tapper, U.: Positive matrix factorization: A non-negative factor model with optimal utilization of error estimates of data values, Environmetrics, 5, 111-126, doi:10.1002/env.3170050203, 1994.

Park, K., Kittelson, D., Zachariah, M., and McMurry, P.: Measurement of Inherent Material Density of Nanoparticle Agglomerates, J. Nanopart. Res., 6, 267-272, doi:10.1023/B:NANO.0000034657.71309.e6, 2004.

Parworth, C., Fast, J., Mei, F., Shippert, T., Sivaraman, C., Tilp, A., Watson, T., and Zhang, Q.: Long-term measurements of submicrometer aerosol chemistry at the Southern Great Plains (SGP) using an Aerosol Chemical Speciation Monitor (ACSM), Atmos. Environ., 106, 43-55, doi:10.1016/j.atmosenv.2015.01.060, 2015.

Paulot, F., Crounse, J. D., Kjaergaard, H. G., Kürten, A., St. Clair, J. M., Seinfeld, J. H., and Wennberg, P. O.: Unexpected Epoxide Formation in the Gas-Phase Photooxidation of Isoprene, Science, 325, 730-733, doi:10.1126/science.1172910, 2009.
Peltier, R. E., Sullivan, A. P., Weber, R. J., Wollny, A. G., Holloway, J. S., Brock, C. A., de Gouw, J. A., and Atlas, E. L.: No evidence for acid-catalyzed secondary organic aerosol formation in power plant plumes over metropolitan Atlanta, Georgia, Geophys. Res. Lett., 34, L06801, doi:10.1029/2006GL028780, 2007.

Petit, J.-E., Favez, O., Sciare, J., Crenn, V., Sarda-Estève, R., Bonnaire, N., Mocnik, G., Dupont, J.-C., Haeffelin, M., and LeozGarziandia, E.: Two years of near real-time chemical composition of submicron aerosols in the region of Paris using an Aerosol Chemical Speciation Monitor (ACSM) and a multiwavelength Aethalometer, Atmos. Chem. Phys., 15, 2985-3005, doi:10.5194/acp-15-2985-2015, 2015.

Pope III, C. A. and Dockery, D. W.: Health Effects of Fine Particulate Air Pollution: Lines that Connect, JAPCA J. Air Waste Ma., 56, 709-742, 2006.

Ripoll, A., Minguillón, M. C., Pey, J., Jimenez, J. L., Day, D. A., Sosedova, Y., Canonaco, F., Prévôt, A. S. H., Querol, X., and Alastuey, A.: Long-term real-time chemical characterization of submicron aerosols at Montsec (southern Pyrenees, $1570 \mathrm{~m}$ a.s.1.), Atmos. Chem. Phys., 15, 2935-2951, doi:10.5194/acp-15-2935-2015, 2015.

Riva, M., Budisulistiorini, S. H., Zhang, Z., Gold, A., and Surratt, J. D.: Chemical characterization of secondary organic aerosol constituents from isoprene ozonolysis in the presence of acidic aerosol, Atmos. Environ., 1-9, doi:10.1016/j.atmosenv.2015.06.027, 2015.

Robinson, A. L., Donahue, N. M., Shrivastava, M. K., Weitkamp, E. A., Sage, A. M., Grieshop, A. P., Lane, T. E., Pierce, J. R., and Pandis, S. N.: Rethinking Organic Aerosols: Semivolatile Emissions and Photochemical Aging, Science, 315, 1259-1262, doi:10.1126/science.1133061, 2007.

Robinson, N. H., Hamilton, J. F., Allan, J. D., Langford, B., Oram, D. E., Chen, Q., Docherty, K., Farmer, D. K., Jimenez, J. L., Ward, M. W., Hewitt, C. N., Barley, M. H., Jenkin, M. E., Rickard, A. R., Martin, S. T., McFiggans, G., and Coe, H.: Evidence for a significant proportion of Secondary Organic Aerosol from isoprene above a maritime tropical forest, Atmos. Chem. Phys., 11, 1039-1050, doi:10.5194/acp-11-1039-2011, 2011.

Rollins, A. W., Browne, E. C., Min, K., Pusede, S. E., Wooldridge, P. J., Gentner, D. R., Goldstein, A. H., Liu, S., Day, D. A., Russell, L. M., and Cohen, R. C.: Evidence for NOx Control over Nighttime SOA Formation, Science, 337, 1210-1212, doi:10.1126/science.1221520, 2012.

Safi Shalamzari, M., Ryabtsova, O., Kahnt, A., Vermeylen, R., Hérent, M., Quetin-Leclercq, J., Van der Veken, P., Maenhaut, W., and Claeys, M.: Mass spectrometric characterization of organosulfates related to secondary organic aerosol from isoprene, Rapid Commun. Mass Spectrom., 27, 784-794, doi:10.1002/rcm.6511, 2013.

Schichtel, B. A., Malm, W.C., Bench, G., Fallon, S., McDade, C. E., Chow, J. C., and Watson, J. G.: Fossil and contemporary fine particulate carbon fractions at 12 rural and urban sites in the United States, J. Geophys. Res., 113, D02311, doi:10.1029/2007JD008605, 2008.

Slowik, J. G., Brook, J., Chang, R. Y.-W., Evans, G. J., Hayden, K., Jeong, C.-H., Li, S.-M., Liggio, J., Liu, P. S. K., McGuire, M., Mihele, C., Sjostedt, S., Vlasenko, A., and Abbatt, J. P. D.: Photochemical processing of organic aerosol at nearby continental sites: contrast between urban plumes and regional aerosol, 
Atmos. Chem. Phys., 11, 2991-3006, doi:10.5194/acp-11-29912011, 2011.

Solomon, P. A., Chameides, W., Weber, R., Middlebrook, A., Kiang, C. S., Russell, A. G., Butler, A., Turpin, B., Mikel, D., Scheffe, R., Cowling, E., Edgerton, E., St. John, J., Jansen, J., McMurry, P., Hering, S., and Bahadori, T.: Overview of the 1999 Atlanta Supersite Project, J. Geophys. Res., 108, 8413-8436, doi:10.1029/2001JD001458, 2003.

St. Clair, J. M., Rivera-Rios, J., Crounse, J. D., Knap, H. C., Bates, K. H., Teng, A. P., Jorgensen, S., Kjaergaard, H. G., Keutsch, F. N., and Wennberg, P. O.: Kinetics and Products of the Reaction of the First-Generation Isoprene Hydroxy Hydroperoxide (ISOPOOH) with OH, J. Phys. Chem. A, 120, 1441-1451, doi:10.1021/acs.jpca.5b06532, 2015.

Sun, Y., Zhang, Q., Zheng, M., Ding, X., Edgerton, E. S., and Wang, X.: Characterization and Source Apportionment of WaterSoluble Organic Matter in Atmospheric Fine Particles $\left(\mathrm{PM}_{2.5}\right)$ with High-Resolution Aerosol Mass Spectrometry and GC-MS, Environ. Sci. Technol., 45, 4854-4861, doi:10.1021/es200162h, 2011.

Surratt, J. D., Murphy, S. M., Kroll, J. H., Ng, N. L., Hildebrandt, L., Sorooshian, A., Szmigielski, R., Vermeylen, R., Maenhaut, W., Claeys, M., Flagan, R. C., and Seinfeld, J. H.: Chemical Composition of Secondary Organic Aerosol Formed from the Photooxidation of Isoprene, J. Phys. Chem. A, 110, 9665-9690, doi:10.1021/jp061734m, 2006.

Surratt, J. D., Lewandowski, M., Offenberg, J. H., Jaoui, M., Kleindienst, T. E., Edney, E. O., and Seinfeld, J. H.: Effect of Acidity on Secondary Organic Aerosol Formation from Isoprene, Environ. Sci. Technol., 41, 5363-5369, doi:10.1021/es0704176, 2007.

Surratt, J. D., Gómez-González, Y., Chan, A. W. H., Vermeylen, R., Shahgholi, M., Kleindienst, T. E., Edney, E. O., Offenberg, J. H., Lewandowski, M., Jaoui, M., Maenhaut, W., Claeys, M., Flagan, R. C., and Seinfeld, J. H.: Organosulfate Formation in Biogenic Secondary Organic Aerosol, J. Phys. Chem. A, 112, 8345-8378, doi:10.1021/jp802310p, 2008.

Szmigielski, R., Surratt, J. D., Gómez-González, Y., Van der Veken, P., Kourtchev, I., Vermeylen, R., Blockhuys, F., Jaoui, M., Kleindienst, T. E., Lewandowski, M., Offenberg, J. H., Edney, E. O., Seinfeld, J. H., Maenhaut, W., and Claeys, M.: 3-methyl1,2,3-butanetricarboxylic acid: An atmospheric tracer for terpene secondary organic aerosol, Geophys. Res. Lett., 34, L24811, doi:10.1029/2007GL031338, 2007.

Tanner, R. L., Parkhurst, W. J., and McNichol, A. P.: Fossil Sources of Ambient Aerosol Carbon Based on ${ }^{14} \mathrm{C}$ Measurements Special Issue of Aerosol Science and Technology on Findings from the Fine Particulate Matter Supersites Program, Aerosol Sci. Technol., 38, 133-139, doi:10.1080/02786820390229453, 2004a.

Tanner, R. L., Parkhurst, W. J., Valente, M. L., and David Phillips, W.: Regional composition of $\mathrm{PM}_{2.5}$ aerosols measured at urban, rural and "background" sites in the Tennessee valley, Atmos. Environ., 38, 3143-3153, doi:10.1016/j.atmosenv.2004.03.023, 2004b.

Tanner, R. L., Bairai, S. T., Olszyna, K. J., Valente, M. L., and Valente, R. J.: Diurnal patterns in $\mathrm{PM}_{2.5}$ mass and composition at a background, complex terrain site, Atmos. Environ., 39, 38653875, doi:10.1016/j.atmosenv.2005.03.014, 2005.
Tanner, R. L., Bairai, S. T., and Mueller, S. F.: Trends in concentrations of atmospheric gaseous and particulate species in rural eastern Tennessee as related to primary emission reductions, Atmos. Chem. Phys., 15, 9781-9797, doi:10.5194/acp-15-97812015, 2015.

Tennessee Valley Authority: TVA Reservoirs and Power Plants, available at: https://www.tva.gov/Environment/ Environmental-Stewardship/Integrated-Resource-Plan (last access: 22 January 2016), 2015.

Turpin, B. J. and Lim, H. J.: Species Contributions to $\mathrm{PM}_{2.5}$ Mass Concentrations: Revisiting Common Assumptions for Estimating Organic Mass, Aerosol Sci. Technol., 35, 602-610, doi:10.1080/02786820119445, 2001.

Ulbrich, I. M., Canagaratna, M. R., Zhang, Q., Worsnop, D. R., and Jimenez, J. L.: Interpretation of organic components from Positive Matrix Factorization of aerosol mass spectrometric data, Atmos. Chem. Phys., 9, 2891-2918, doi:10.5194/acp-9-2891-2009, 2009.

Wood, E. C., Canagaratna, M. R., Herndon, S. C., Onasch, T. B., Kolb, C. E., Worsnop, D. R., Kroll, J. H., Knighton, W. B., Seila, R., Zavala, M., Molina, L. T., DeCarlo, P. F., Jimenez, J. L., Weinheimer, A. J., Knapp, D. J., Jobson, B. T., Stutz, J., Kuster, W. C., and Williams, E. J.: Investigation of the correlation between odd oxygen and secondary organic aerosol in Mexico City and Houston, Atmos. Chem. Phys., 10, 8947-8968, doi:10.5194/acp-10-8947-2010, 2010.

Worton, D. R., Surratt, J. D., LaFranchi, B. W., Chan, A. W. H., Zhao, Y., Weber, R. J., Park, J., Gilman, J. B., de Gouw, J., Park, C., Schade, G., Beaver, M., Clair, J. M. S., Crounse, J., Wennberg, P., Wolfe, G. M., Harrold, S., Thornton, J. A., Farmer, D. K., Docherty, K. S., Cubison, M. J., Jimenez, J., Frossard, A. A., Russell, L. M., Kristensen, K., Glasius, M., Mao, J., Ren, X., Brune, W., Browne, E. C., Pusede, S. E., Cohen, R. C., Seinfeld, J. H., and Goldstein, A. H.: Observational Insights into Aerosol Formation from Isoprene, Environ. Sci. Technol., 47, 11403-11413, doi:10.1021/es4011064, 2013.

Xu, L., Suresh, S., Guo, H., Weber, R. J., and Ng, N. L.: Aerosol characterization over the southeastern United States using highresolution aerosol mass spectrometry: spatial and seasonal variation of aerosol composition and sources with a focus on organic nitrates, Atmos. Chem. Phys., 15, 7307-7336, doi:10.5194/acp15-7307-2015, 2015a.

Xu, L., Guo, H., Boyd, C. M., Klein, M., Bougiatioti, A., Cerully, K. M., Hite, J. R., Isaacman-VanWertz, G., Kreisberg, N. M., Knote, C., Olson, K., Koss, A., Goldstein, A. H., Hering, S. V., de Gouw, J., Baumann, K., Lee, S., Nenes, A., Weber, R. J., and $\mathrm{Ng}$, N. L.: Effects of anthropogenic emissions on aerosol formation from isoprene and monoterpenes in the southeastern United States, P. Natl. Acad. Sci. USA, 112, 37-42, doi:10.1073/pnas.1417609112, 2015b.

Yasmeen, F., Vermeylen, R., Szmigielski, R., Iinuma, Y., Böge, O., Herrmann, H., Maenhaut, W., and Claeys, M.: Terpenylic acid and related compounds: precursors for dimers in secondary organic aerosol from the ozonolysis of $\alpha$ - and $\beta$-pinene, Atmos. Chem. Phys., 10, 9383-9392, doi:10.5194/acp-10-9383-2010, 2010.

Zhang, H., Surratt, J. D., Lin, Y. H., Bapat, J., and Kamens, R. M.: Effect of relative humidity on SOA formation from isoprene/NO photooxidation: enhancement of 2-methylglyceric acid and its 
corresponding oligoesters under dry conditions, Atmos. Chem. Phys., 11, 6411-6424, doi:10.5194/acp-11-6411-2011, 2011.

Zhang, Q., Jimenez, J. L., Canagaratna, M. R., Allan, J. D., Coe, H., Ulbrich, I., Alfarra, M. R., Takami, A., Middlebrook, A. M., Sun, Y. L., Dzepina, K., Dunlea, E., Docherty, K., DeCarlo, P. F., Salcedo, D., Onasch, T., Jayne, J. T., Miyoshi, T., Shimono, A., Hatakeyama, S., Takegawa, N., Kondo, Y., Schneider, J., Drewnick, F., Borrmann, S., Weimer, S., Demerjian, K., Williams, P., Bower, K., Bahreini, R., Cottrell, L., Griffin, R. J., Rautiainen, J., Sun, J. Y., Zhang, Y. M., and Worsnop, D. R.: Ubiquity and dominance of oxygenated species in organic aerosols in anthropogenically-influenced Northern Hemisphere midlatitudes, Geophys. Res. Lett., 34, L13801, doi:10.1029/2007GL029979, 2007.

Zhang, Q., Worsnop, D. R., Canagaratna, M. R., and Jimenez, J. L.: Hydrocarbon-like and oxygenated organic aerosols in Pittsburgh: insights into sources and processes of organic aerosols, Atmos. Chem. Phys., 5, 3289-3311, doi:10.5194/acp-5-3289$2005,2005$.
Zhang, Q. Q.: Understanding atmospheric organic aerosols via factor analysis of aerosol mass spectrometry: a review, Anal. Bioanal. Chem., 401, 3045-3067, 2011.

Zhang, Y. J., Tang, L. L., Wang, Z., Yu, H. X., Sun, Y. L., Liu, D., Qin, W., Canonaco, F., Prévôt, A. S. H., Zhang, H. L., and Zhou, H. C.: Insights into characteristics, sources, and evolution of submicron aerosols during harvest seasons in the Yangtze River delta region, China, Atmos. Chem. Phys., 15, 1331-1349, doi:10.5194/acp-15-1331-2015, 2015. 